Scottish Journal of Geology, Volume 50, 1-25, 2014.

Note that this version of the text does not include all of the final amendments added in proof by the $S J G$ editor.

\title{
A review of geological origins and relationships in the Ballantrae Complex, SW Scotland
}

\author{
Philip Stone \\ British Geological Survey, Murchison House, West Mains Road, \\ Edinburgh EH9 3LA, UK. (e-mail: psto@bgs.ac.uk)
}

\section{Synopsis}

A substantial history of research has established the Ballantrae Complex as an ophiolite assemblage, generated within the Iapetus Ocean and accreted at the margin of Laurentia as that ocean began to close. Radiometric dates and graptolite biostratigraphy provide an age range from Neoproterozoic (rarely and questionably) to early Ordovician (commonly and securely). Components of the complex formed in a range of oceanic environments: within-plate oceanic islands, island arcs and backarc spreading zones. Overall, the various lines of evidence point to an early Arenig marginal basin, incorporating some older elements, which was tectonically disrupted and compressed during an obduction event driven by arc-continent collision. Despite the general consensus as to the age and origin of the complex there remain areas of uncertainty. It is highly probable that some components of the complex that are now structurally juxtaposed originated at a considerable distance from each other both horizontally and vertically. Further, the sporadic presence of high-grade metamorphic rocks - notably blueschists - suggests a complicated and probably polyphase structural history, whilst the relative importance of serpentinite diapirism versus compressional and strike-slip tectonics remains unresolved. In terms of regional structure, the complex appears to occupy a steeply inclined fault zone, separating the Midland Valley from the Southern Uplands terrane to the south, to a depth of several 
kilometres. This situation questions the concept of the complex as the vestige of an ophiolite sheet obducted onto the Midland Valley basement.

\section{Preamble}

Within the Caledonian Orogen are a number of structurally isolated ophiolitic assemblages of Cambro-Ordovician age, that trace the vestiges of the Iapetus Ocean from Norway and Shetland in the north-east to Newfoundland and beyond in the south-west. Between Girvan and Ballantrae, in south-west Scotland, one such ophiolite complex occupies a position at the boundary between the Scottish Midland Valley and Southern Uplands terranes (Figure 1). There is an extensive literature on this, the Ballantrae Complex, which was initially stimulated by the range of unusual lithologies present but was then much expanded as the importance of the ophiolitic assemblage to plate tectonic models of the Caledonian Orogen became clear (e.g. Dewey 1971, Van Staal et al. 1998 and references therein). Accordingly, several of the key sections and exposures at Ballantrae are now designated as Sites of Special Scientific Interest (Stone 1999). This paper reviews the history of research that has contributed to the modern understanding of the complex and assesses its status in a regional context, building on the excellent summary of the complex's geology by Bluck (in Oliver et al. 2002, from the fourth edition of The Geology of Scotland) and the earlier comprehensive description by Stone \& Smellie (1988). The time scale used throughout is that of Gradstein et al. (2012).

\section{Introduction}

The Ballantrae Complex is a tectonised assemblage of mainly igneous rocks of Late Cambrian or Early Ordovician (mostly Arenig) age that originated as the various components of the oceanic crust and mantle. When accreted at a continental margin, and in an ideal state of preservation, ophiolite complexes preserve the quasistratigraphical succession of the ocean crust and mantle: a basal ultramafic component passing upwards through gabbros and sheeted dykes into a volcanic and volcanosedimentary succession dominated by submarine pillow lavas, all capped by deep 
marine sedimentary rock (e.g. Coleman 1977). However, in common with many ancient ophiolites, only disaggregated parts of this succession are present in the Ballantrae Complex, which crops out over about $75 \mathrm{~km}^{2}$ between Girvan and Ballantrae (British Geological Survey 1988) on the Ayrshire coast of the Firth of Clyde. The complex lies immediately to the north of the Stinchar Valley Fault, the local expression of the Southern Upland Fault, which forms its southern boundary (Figure 1a, b). Geophysical evidence suggests an eastwards extension beneath the unconformable cover of younger sedimentary rocks. The oldest strata within that overlying cover sequence are of Early Llanvirn age (Williams 1962), which provides an upper temporal limit for the tectonic assembly of the Ballantrae Complex.

Despite its relatively small outcrop area, the Ballantrae Complex comprises a bewildering variety of ophiolitic rock types. Two main elements dominate, interleaved by faulting: serpentinised ultramafic rocks derived from the oceanic mantle, and volcanic sequences interpreted as the remains of island arcs and ocean crust and islands. Major NE-SW faults define the discrete lithological zones such that Northern and Southern Serpentinite belts (descriptive names in common usage) now separate three areas of mainly volcanic rock (Figure 1c). These contrasting lithologies, now in structural contact, originated over a considerable depth range in the oceanic crust and mantle but they are all believed to have originally formed in the Iapetus Ocean close to its northern margin with Laurentia. Palaeomagnetic results from one of the Arenig volcanic components suggests a palaeolatitude of about $29^{\circ}$ South (Trench et al. 1988).

Basaltic pillow lavas are widespread throughout the volcanogenic outcrops and their orientations show that 'bedding' dips are generally steep; the sense of younging shown by the pillow shapes is locally consistent but regionally variable. However, overall there is a preponderance of younging towards the north-west and this influenced the suggestion by Lewis and Bloxam (1977) that most of the Ballantrae lavas originally formed a single succession, at least $5 \mathrm{~km}$ thick, which was split by the "cross-cutting dilational emplacement" of the serpentinite bodies. This interpretation was subsequently undermined in two ways: by the demonstration of significant compositional differences between the various pillow lava outcrops and by the distribution of the sparse graptolite faunas from rare sedimentary interbeds. These 
aspects will be considered more fully later in this account, but at this stage it is worth noting that Bluck (1982) demonstrated that a conformable volcanogenic succession approximately $1700 \mathrm{~m}$ thick forms the Pinbain Hill outcrop (Figure 1c), whilst Stone \& Rushton (1983) showed that at Bennane Head a succession about 750 m thick has been structurally repeated several times.

The compositional variations amongst the volcanic rocks show that they were erupted in several entirely different oceanic regimes, and it is clear that only tiny fragments derived from each have been preserved and juxtaposed. The environment of volcanism can be established by the trace element content of the basaltic lavas produced (e.g. Pearce \& Cann 1973; Pearce \& Norry 1979); either an island arc formed above a subduction zone, or an ocean island (producing lavas also known as within-plate or Hawaiian-type) or a mid-ocean ridge (producing basalts known by the acronym MORB). A series of analytical studies has established that the Ballantrae Complex lavas are polygenetic (e.g. Thirlwall \& Bluck 1984; Smellie \& Stone 2001) with all three of the main environment types represented and the island arc varieties showing clear subdivisions; an indication of the distribution of the different lava types is shown in Figure 2.

With oceanic subduction being an important process in generation of the Ballantrae rocks, their structural juxtaposition can be envisaged as arising from the destruction of the oceanic, arc-dominated environment during its collision with the continental margin of Laurentia. The timing of this collision makes it a part of the Grampian Event (ca $470 \mathrm{Ma}$ ) of the Caledonian Orogeny (McKerrow et al. 2000; Stone \& Rushton 2003). Thrust sheets derived from the ophiolitic assemblage were emplaced onto the continent, the process of obduction, and in this respect one important feature of the Ballantrae Complex is the thin zone of dynamothermal metamorphic rocks forming a high-temperature sear zone adjacent to the south-east margin of the Northern Serpentinite Belt (Figure 1c). This has been taken to indicate the tectonic passage of hot, mantle-derived ultramafic rocks up and across the cooler volcanic rocks forming the higher parts of the ophiolite 'stratigraphy', a process discussed in more detail later in this review. However, whilst compressive subduction-obduction movements might produce the structural assemblage of rock types present in the Ballantrae Complex, it could probably be achieved more readily with additional 
components of back-arc extension and strike-slip tectonics; again, further discussion will follow.

The enormous scale of the original palaeogeography now represented by the amalgamated vestiges of the Ballantrae Complex cannot be over-emphasised. Van Staal et al. (1998) compared the northern margin of the Iapetus Ocean, the eventual focus of the Caledonian-Appalachian Orogen, to the situation derived from forwardmodelling of the present-day west and south-west Pacific Ocean. They concluded that after hundreds of kilometres of convergence, oceanic elements might still broadly preserve along strike coherence for several thousand kilometres, although excision or duplication was highly likely, either during oblique, strike-slip convergence or terminal collision. During these events, mantle ultramafic rocks might readily be juxtaposed against extrusive lavas. The likelihood of huge and probably anastomosing fault displacements must be acknowledged in any discussion of the Ballantrae Complex's tectonic assembly. Finally, it is appropriate to end this introduction with an admission. Although the area has been the focus of considerable research there is still much to be discovered about the origins of the Ballantrae Complex, and it remains one of the most enigmatic geological features of southern Scotland.

\section{The development of the geological model}

Early contributions to the geological investigation of the Ballantrae Complex have been summarised by Anderson (1936) and Bailey \& McCallien (1952), and in more recent accounts by Stone \& Smellie (1988) and Bluck (in Oliver et al. 2002). The first of many controversies was sparked by James Geikie's (1866) interpretation of the complex as an assemblage of metamorphosed, Lower Palaeozoic limestone, sandstone and shale. Geikie's ideas were vehemently opposed by Forbes (1867) who argued for an igneous origin, and an acrimonious correspondence followed. Nevertheless, the metamorphic model was maintained by Archibald and James Geikie (1869) in the Memoir accompanying the first Geological Survey map of the district. The igneous character of the Ballantrae rocks had been previously recognised by Murchison and Nicol (Murchison 1851), but it was left to Bonney (1878) to unequivocally establish the igneous origin, drawing on his familiarity with the similar lithologies exposed on the Lizard peninsula, Cornwall, in south-west England; Murchison (1851, p. 153) had 
briefly noted the same comparison. However, though Bonney was correct in his petrographical assessment, he had little evidence as to the age of the rocks, and so related the lavas and agglomerates to the established Early Devonian volcanic episode of southern Scotland, with the serpentinite as a younger intrusion. This instigated the next round of Ballantrae controversy: arguments over the age of the rocks.

The first definitive contribution to the age debate was made by Lapworth (1889) who recovered Arenig graptolites from sedimentary interbeds in the lava sequence to the south of Bennane Head; but the serpentinite was still regarded as a younger, possibly post-Silurian intrusion. Then, in their seminal Geological Survey Memoir, Peach \& Horne (1899) added additional Arenig graptolite localities within the lava-dominated successions but favoured a similar Arenig age for intrusion of the serpentinite. In this they were probably influenced by Teall's contribution to the memoir in which he noted the close association within the Ballantrae Complex (and elsewhere) of serpentinite, gabbro and pillow lava and observed that some difficulty was experienced in determining the precise relations of the plutonic and volcanic rocks. As stressed by Bailey \& McCallien (1952, p. 26), Teall was presciently moving towards recognition of the 'ophiolitic', serpentinite - basalt/spilite pillow lava - chert assemblage that later became known as the 'Steinmann Trinity' (see Coleman (1977, pp 1-3) for a history of the term's adoption).

This apparent resolution of the age relationships survived unchallenged for some time until Balsillie (1932) expressed dissatisfaction in an important paper that detailed for the first time much of the lithological variation within the complex. Whilst Balsillie provided no new overall interpretation, he opined that the presumed intrusive serpentinite-lava relationship was in need of revision. Shortly after, Pringle (1933) suggested that the serpentinite might actually form a Precambrian basement to an unconformable cover of Arenig lavas, a model that he maintained in the 1935 first edition of the Geological Survey's South of Scotland volume in the British Regional Geology series. Balsillie pursued the same interpretation in a private publication (Balsillie 1935) and a letter to The Scotsman newspaper (Balsillie 1936) before, in a more conventional scientific medium, he reiterated the case for a Precambrian basement to the Early Ordovician lavas based on his discovery of foliated, high-grade, metamorphic rocks associated with the serpentinite bodies Balsillie (1937). This was 
the first formal record of blueschist and garnet-metapyroxenite within the Ballantrae Complex, although the metapyroxenite had been mentioned (described as eclogite and related to the Lewisian) in Balsillie's 1936 letter to The Scotsman.

In parallel with Balsillie's publications (and provoking some rather tetchy correspondence), Anderson (1936) had produced fresh evidence for the serpentinite having apparently intruded the lavas. But Anderson also stressed the 'Steinmann Trinity' association of the Ballantrae rocks and was perhaps the first to apply the term 'ophiolite' to the whole Ballantrae assemblage, which (like Teall) he compared to Alpine examples (in his 1866 paper James Geikie had used 'ophiolite' as a broad synonym for serpentinite following the common usage of the time). To quote from Anderson's paper: “Ophiolite is a general term including serpentine, gabbro and spilite, and authors are agreed that all three are intimately associated in time as well as in space, and, in fact, are comagmatic. [A]s they are commonly associated with deepsea deposits it is considered they were formed under abyssal conditions." This definition would have been widely accepted by Anderson's European contemporaries following Steinmann's (1927) formalisation of the ophiolite concept, based largely on work on the Alps.

Anderson's description sounds remarkably close to a modern 'ophiolitic' interpretation, but was not left unchallenged. Bailey \& McCallien (1957) established that much of the evidence that had been taken as proving an intrusive relationship between the serpentinite and the lavas in fact arose from secondary veining produced during the serpentinisation of the original ultramafic protolith. They were also impressed by, and replicated, Balsillie's evidence for an apparently unconformable relationship, notably the presence of gabbro and serpentinite fragments within breccias from the lava sequence (described by them as agglomerates). To accommodate all of the evidence Bailey \& McCallien proposed that the serpentinite had been erupted as a huge submarine 'lava' flow intervening between phases of basaltic eruption. Subsequent large-scale folding and erosion then, they thought, produced the alternating belts of lava and serpentinite now seen at outcrop. This interpretation does not seem to have found much support, perhaps because of a series of papers by Bloxam describing petrological and metamorphic complexities that did not sit easily with the Bailey \& McCallien model. Aspects of the mineralogical 
changes arising during serpentinisation were described by Bloxam $(1954,1964)$, high grade metamorphic rocks (beerbachite, glaucophane schist and 'eclogite') were described by Bloxam (1955) and by Bloxam and Allen (1960), and an unusual 'plagiogranite' lithology was identified and described by Bloxam (1968). These observations were soon to become of greater significance as, within a few years, the plate tectonic revolution began to provide a very different template for the Ballantrae Complex.

The impact of plate tectonics

Amongst the first of the attempts to incorporate the Ballantrae Complex in a plate tectonic interpretation of the Caledonian orogen was that by Dewey (1971). Therein, Dewey clearly associated the Ballantrae rocks as an ophiolite derived from oceanic crust and mantle. For example, in discussion (p. 224) of the Franciscan mélange as an accumulation of oceanic materials (argillites, cherts, detached ophiolite complexes) in a Mesozoic trench, Dewey writes: "Upthrust wedges of ophiolite (oceanic crust and mantle) commonly occur behind the trench ... and may represent thrust-emplacement during the initial phases of trench development or slices torn from the descending slab and packed against the leading plate-edge." Then (pp 226-227: "The Ballantrae Complex is believed to represent the basement of the southern part of the Midland Valley and be an upthrust wedge of oceanic crust and mantle ... If the writer is correct in supposing the Ballantrae Complex to represent oceanic crust and mantle generated at an oceanic ridge, this crust and mantle was soon afterwards tectonically incorporated against the continental margin by underthrusting and affected by blueschist metamorphism." Dewey then cites a range of authors to establish that "underthrusting in oceanic trenches is the essential cause of blueschist metamorphism." Significantly, in the light of subsequent work, Dewey goes on to argue (pp 234-235) that the development of the Early Ordovician, Caledonian ophiolite complexes, specifically including Ballantrae, "was not during the Cambrian opening of a Proto-Atlantic ocean, but in small ocean basins, similar to those of the western Pacific ... the Ballantrae Complex may have originated by marginal sea-floor spreading”. Church \& Gayer (1973) provided a more detailed assessment of the components of the Ballantrae Complex as an ophiolitic assemblage, but the first attempts at geochemical discrimination of the lava sequences by Bloxam \& Lewis 
(1972) and by Wilkinson \& Cann (1974) hinted at the presence not of mid-ocean ridge basalts but of island arc and oceanic island (within-plate 'hot-spot') lavas. From these beginnings, the marginal basin model was refined by Bluck (1978) and Bluck et al. (1980), whilst lithofacies evidence interpreted as favouring within-plate volcanism was emphasised by Barrett et al. (1981, 1982).

As more geochemical data were gathered (e.g. Thirlwall \& Bluck 1984; Stone \& Smellie 1990; Smellie \& Stone 1992, 2001) it became clear that the volcanic parts of the Ballantrae complex were indeed polygenetic (Figure 2). Of the various models developed to accommodate all of the disparate components within a broadly arc to back-arc situation, two are summarised in Figure 3. In Figure 3a and b, after Smellie $\&$ Stone (2001), all elements of the Ballantrae Complex are accommodated within an evolving arc split by back-arc spreading to create a back-arc basin; within-plate lavas were generated on the 'relic arc' side of the basin. A more recently proposed alternative, shown in Figure 3a and c after Kawai et al. (2008), envisages that following supra-subduction zone arc volcanism, ridge subduction encouraged slab break-off to create a window in the descending oceanic crust. In this situation lavas with the geochemical characteristics of within-plate basalts can be erupted close to arc-generated basaltic lavas in both time and space.

As an alternative to the 'integrated' interpretations of Figure 3, the range and complexity of the geological components present in the Ballantrae Complex may also be addressed in two other ways. Firstly, Bluck (1985, 2001, and in Oliver et al. 2002) envisaged a series of obduction/accretion events alternating with phases of renewed marginal basin extension and volcanism so that different components of the complex were formed at different times as the geotectonic regime changed and evolved. Secondly, the different components may not all have formed in proximity, but might instead have been brought together by tectonic means. Stone (1984) argued for the strike-slip assembly of the complex, and in possible support of that mechanism it is worth noting that geophysical evidence, in particular the results of magnetic modelling (Kimbell \& Stone 1995) shows the Ballantrae Complex to have a steeply inclined extension for at least $30 \mathrm{~km}$ along strike to the north-east, in a narrow zone adjacent to the north side of the Stinchar Valley - Southern Upland Fault and buried beneath younger rocks (Figure 4, section A-B). As modelled, this zone of ophiolitic 
rocks extends downwards to a depth of about 6 or $7 \mathrm{~km}$ and appears to separate broadly similar basement blocks with geophysical characteristics compatible with metamorphosed Lower Palaeozoic rock. Within the complex itself the ophiolitic lithologies have structurally complicated relationships, but two main elements dominate, interleaved by faulting: serpentinised ultramafic rocks derived from the oceanic mantle, and volcanic sequences representing the remains of island arc and oceanic crust. The principal structures are steeply-inclined, NE-SW-trending faults that run sub-parallel to the Stinchar Valley - Southern Upland Fault and split the complex into discrete lithological zones: the principal of these are the Northern and Southern Serpentinite belts and the three areas of mainly volcanic rock that they separate (Figure 1c). This pattern could be viewed as a series of strike-slip, lateral duplexes in a steeply inclined shear zone, particularly as the majority of fabrics within the complex, whether 'bedding' in lava successions or tectonic cleavage/foliation, are similarly steeply inclined.

At this point in the Ballantrae Complex narrative, with a range of possible development models in play, it is appropriate to consider the various lithological components in greater detail. These are described sequentially in the following sections so that a more informed reassessment of the origins and geological history of the complex can then be attempted.

\section{Ultramafic rocks}

Within the Ballantrae Complex, the ultramafic rocks have been pervasively altered, with serpentine replacing the original olivine to produce a dark-green to black, generally fine-grained rock, locally containing yellowish-green, bastite pseudomorphs of altered orthopyroxene. Locally, the ultramafic rock is composed mainly of varying proportions of ortho- and clinopyroxene. All of the serpentinised ultramafic lithologies are relatively soft and readily eroded, so that exposure of the serpentinite is very limited. Complex veining by quartz and carbonate is a general feature of the faulted margins to the ultramafic bodies. The distribution of the ultramafic rocks within the Ballantrae Complex is shown in Figure 5. 
The olivine-rich ultramafic rocks originally crystallized within oceanic mantle and their compositions indicate that they are residues after the extraction of a basaltic melt (Jelínek et al. 1984). However, subtle but significant differences in composition between the two main outcrops, the Northern and Southern Serpentinite belts, show that they do not share the same history of formation. The northern serpentinite is the more metasomatised of the two and most probably originated in a supra-subduction zone, sub-arc environment. The southern serpentinite, though still metasomatised, also has some of the characteristics of mid-ocean mantle, a hybrid condition perhaps originating in a back-arc setting. To accentuate these differences between the two main serpentinite belts, the following account will utilise rock names reflecting the original composition of the rocks, prior to serpentinization, as detailed by Stone \& Smellie (1988), following Coleman (1977, fig. 4).

The Northern Serpentinite Belt (Figure 5) is composed mainly of harzburgite (olivine with accessory orthopyroxene) with some lherzolite (olivine with both accessory orthopyroxene and clinopyroxene) and a variety of pyroxenites. Concentrations of finely disseminated chromite are present locally (Stone et al. 1986), with a notable occurrence near Pinbain Bridge (Figure 5), and are associated with accessory platinum-group minerals (Power \& Pirrie 2003). A pronounced mineral banding is present in places, produced by alternating enstatite- and olivine-rich layers between 1 $\mathrm{mm}$ to $5 \mathrm{~cm}$ thick (Jones 1977). There is also a widespread, steeply inclined tectonic fabric that is strongly developed adjacent and sub-parallel to the sheared south-eastern margin of the serpentinite body, as first recognised by Balsillie (1932). In contrast, the southern serpentinite has either no tectonic fabric or one that is only weak and localised, and also has a slightly different lithological assemblage to that seen in the north. In the southern belt, although harzburgite is again dominant, it is generally coarser grained than in the north and is accompanied by dunite ( $>90 \%$ olivine), wherlite (olivine with accessory clinopyroxene) and troctolite (olivine-rich gabbro). At one locality, Poundland Burn (Figure 5), a local concentration of chrome spinel grains forms a distinctive nodular lithology but lacks accessory platinum-group minerals (Stone et al. 1986; Power \& Pirrie 2003). The overall implication is that, quite apart from their different geotectonic environments, the ultramafic protolith of the southern serpentinite formed at a substantially shallower depth then its northern counterpart (Stone \& Smellie 1990). 
The detailed chemistry of rocks from both ultramafic belts, and also of the chrome spinel grains that they contain, is anomalous for normal ocean lithosphere and suggests that they were derived from metasomatised mantle above a subduction zone (Stone \& Smellie 1990). Compositional indicators of a supra-subduction zone origin, established in principle by Pearce et al. (1984) and noted at Ballantrae by Stone \& Smellie (1990) include:

- Harzburgite is the dominant lithology throughout, with lherzolite appearing as only a minor component in the south.

- The harzburgites are generally depleted in a range of elements, most notable titanium, and in addition contain high-chrome spinels shown by Dick \& Bullen (1984) to be more common in ultramafic rocks from arc environments relative to those rocks from abyssal settings.

- Within the cumulate lithologies of the southern belt, wehrlite is common whereas troctolite occurs only rarely.

Between the two principal serpentinite belts, a central zone of small ultramafic inliers is contained within an anastomosing fault network (Figure 5); some are unexposed but have a distinctive geophysical signature (Powell 1978) and have been proved by boreholes (Stone et al 1984). Closely associated with one of the ultramafic inliers, at Knockormal, are foliated meta-basalts containing blue amphibole, and garnethornblende-clinopyroxenite that was originally described as 'eclogite' (Balsillie 1936, 1937) but subsequently proved to have non-eclogitic mineral chemistry (Smellie \& Stone 1984). This assemblage of lithologies was thought by Church \& Gayer (1973) to be possible components of a sedimentary mélange or olistostrome, though the same assemblage was later described by Bloxam (1980) as being contained in a serpentinite-hosted mélange. Though the field relationships are far from clear, the interpretation as a serpentinite-hosted mélange arising from diapirism has been recently reiterated by Kawai et al. (2008). The hornblende-garnet clinopyroxenite was discussed in some detail by Bloxam \& Allen (1960) and a Sm-Nd radiometric age of $576 \pm 32$ Ma was reported by Hamilton et al. (1984), who also dated a similar metapyroxenite from the metamorphic aureole beneath the northern serpentinite near Knocklaugh Bridge (Figure 5) at $505 \pm 11 \mathrm{Ma}$. Both of these pyroxenites were 
considered by Smellie \& Stone (1984) to have originated as segregations in mantle harzburgite, but the metamorphic aspects will be discussed below, in a subsequent section.

\section{Volcanic and associated sedimentary rocks}

The volcanogenic sequences within the complex are dominated by pillow lavas produced during submarine eruptions and the breccias derived from them. A number of formations have been defined locally, but all of the volcanic rocks were included by Stone \& Smellie (1988) within the Balcreuchan Group, named after Balcreuchan Port [NX 098 876], a cave in the cliffs of which is claimed to have been the home in the early $17^{\text {th }}$ century of the legendry Sawney Beane and his cannibal family (Sanders 1760). Some parts of the group comprise uniform accumulations of dark greenishgrey, mainly aphyric, basalt pillows, whereas other sections show alternations of aphyric and coarsely feldsparphyric lavas, reddened in places, interbedded with sedimentary layers of chert and shale and merging vertically and laterally with thick breccia units. The lavas are tough and resistant to erosion so that they form most of the high ground within the complex and create some spectacularly rugged coastal sections. The latter, near Pinbain Bridge and at Bennane Head, have resulted in the volcanic successions exposed therein being relatively well-studied by comparison to the less well-exposed volcanic successions inland.

Following the early geochemical work mentioned previously, a series of analytical studies (e.g. Thirlwall \& Bluck 1984, Stone \& Smellie 1990; Smellie \& Stone 1992, 2001) has established that the Ballantrae Complex lavas are polygenetic, with MORBlike or more probably back-arc basin basalts (BABB), island arc rocks and withinplate basalts all present, and with the island arc varieties showing clear subdivisions; an indication of the distribution of the different lava types is shown in Figure 2. For such geotectonic characterisation, the important indicators are the abundance and ratio proportions of elements that are likely to have been immobile through alteration conditions below those of the greenschist facies. These include titanium (as $\left.\mathrm{TiO}_{2}\right)$, high field strength elements such as zirconium, niobium yttrium and chromium, and the rare earth elements: see Smellie \& Stone (2001) for discussion and references. Examples of geochemical plots illustrating the range of lava types present in the 
Ballantrae Complex are shown in Figure 6. The oceanic affinities of the volcanic rocks were emphasised by the positive $\varepsilon N d t$ values reported by Thirlwall $\&$ Bluck (1984).

Within plate (ocean island or Hawaiian-type) lavas

The tectonic slicing of the complex into numerous fault-defined structural blocks prevents the establishment of a comprehensive stratigraphy, but lithostratigraphical similarities are apparent between some of the blocks: for example, the mixed volcanic-sedimentary sequences at Pinbain Hill, Bennane Head and Knockdolian (Figure 2). All of these mixed lava (aphyric and feldsparphyric) and mostly volcanogenic sedimentary rock associations prove to be of exclusively ocean island (within-plate) affinity, as determined from the distinctively similar geochemistry of their basaltic lavas. Based on a variety of lithofacies features, Smellie \& Stone (2001) suggested that the Bennane Head sequence is a deeper-water equivalent of that at Pinbain Hill. In both successions, graptolites from mudstone and chert layers that are interbedded with the volcanic rocks establish an Early Arenig age (Peach \& Horne 1899; Dewey et al. 1970; Stone \& Rushton 1983; Rushton et al. 1986); conodonts and radiolaria from the chert support the Arenig age (Rushton \& Stone 1988; Aitchison 1998). Zircons from tuff interbeds near the top of the Bennane Head succession (on the south side of Bennane Head, at Bennane Lea) have been dated (U-Pb) by Sawaki et al. (2010) at 470 $\pm 10 \mathrm{Ma}$, giving an age range that spans the Early and Middle Ordovician. Sawaki et al. claim to have sampled zircons from five separate tuff beds, but they do not seem to have taken into account the tight folding of the Bennane Lea section, which means that the same bed may have been sampled more than once. This would not affect the validity of the U-Pb date, but may have implications for their overall structural interpretation, as will be discussed later. More generally in the Bennane Head succession, the distribution of the graptolite faunas, coupled with distinctive changes in lithofacies, establishes at least three major tectonic repetitions of the stratigraphy. Such structural complications undermine attempts to estimate the thickness of the lava succession, both at Bennane Head and more widely.

The presence of graptolitic mudstone and chert might imply fairly deep-water conditions but, conversely, some sedimentary features of these ocean island sequences 
such as rounded clasts in breccias and prograding hyaloclastite deltas (Bluck 1982), and reddened tops to some lava flows and rare volcanic lapilli tuff beds (Smellie 1984a) indicate relatively shallow water conditions or even sporadic and temporary emergence of the lava pile. The evidence can be taken to indicate a variable and unstable depositional environment but, for the Bennane Head succession, Bluck (1992) has emphasised the difficulty in reconciling all of the features present. In particular, he points to his observations of "tuff bands with acid-basic lithologies, layers of crystal tuff and the presence of glass shards within the cherts". These features would seem to be more characteristic of arc volcanicity than of that associated with the within-plate, ocean island environment indicated by the geochemistry of the lavas.

One explanation for the contradictory evidence at Bennane Head might be the contemporaneous and relatively proximal eruption of different volcano types, such that air-fall, arc-derived tuffs were deposited onto an area of active ocean-island volcanism. Another example that more convincingly demonstrates that different depositional regimes were in relatively close proximity is seen at Pinbain Bridge. There, at the base of the Pinbain Hill succession of within-plate lavas, is a unit of volcaniclastic sandstone (the Kilranny Hill Formation) with the geochemical characteristics of a mature island arc, characteristics that are shared with the Mains Hill lavas farther to the south (Figure 2). At Pinbain Bridge, the Kilranny Hill Formation also contains early Arenig graptolites (Rushton et al. 1986).

\section{Island arc lavas}

The pillow lava accumulations of island arc origin contain little interbedded sedimentary rock, with the exception of some thick units of coarse volcanogenic breccia. Most of the lavas are aphyric but some contain pyroxene phenocrysts, in particular those at Mains Hill and to a lesser extent those at Games Loup. The radiometric $(\mathrm{Sm}-\mathrm{Nd})$ dates of $501 \pm 12$ and $476 \pm 14$ Ma that have been obtained, respectively, from these two localities (Thirlwall \& Bluck 1984) span the late Cambrian and early Ordovician. Of particular interest in the Games Loup to Balcreuchan Port section is the presence of lavas with an unusual composition: relatively high silica content accompanied by high levels of $\mathrm{MgO}, \mathrm{Cr}$ and $\mathrm{Ni}$ (Smellie 
et al. 1995). Such lavas, known as boninites, are characteristic of eruption in an oceanic, but supra-subduction setting and modern examples are typically found in the forearc region of volcanic island arcs or as the earliest products of back-arc spreading (e.g. Crawford 1989). If the Games Loup boninites are taken to indicate crustal extension in a back-arc basin, the likely age difference between these relatively primitive arc rocks and the more evolved, mature arc basalts of Mains Hill and Bargain Hill, permits the latter to be interpreted as part of an early-formed volcanic arc that was split by supra-subduction zone extension (Smellie \& Stone 2001). Subsequent within-plate eruptions and gabbroic intrusion then took place in the ensuing back-arc basin. This is the tectonic model illustrated in Figure 3 (a and c) but note that, as previously emphasised, there are alternative interpretations.

\section{Back-arc basin or mid-ocean ridge basalts (BABB or MORB)}

Lavas with the geochemical characteristics of eruption in an extensional environment at a mid-ocean ridge are relatively uncommon in the Balcreuchan Group. The closest association is shown by basalts in the central part of the Ballantrae Complex that lie in a zone along the northern margin of the southern serpentinite between Knockdaw and Knockormal hills (Figure 2). Though the composition of these basalts differs in several subtle respects from the normal MORB type, it compares closely with that of basalts generated at some back-arc spreading centres, i.e. BABB varieties (Smellie \& Stone 2001).

\section{Sheeted Dykes}

The likely presence of basalt lavas generated at spreading ridges, either mid-ocean or back-arc, raises the issue of sheeted dykes, which would form an integral part of the ophiolite assemblage but which, within the Ballantrae Complex, are mostly notable by their absence. Church \& Gayer (1973) tentatively proposed that an array of dykes intruded into gabbro at Millenderdale (Figures 1c and 2) might represent part of a sheeted complex, but Bluck (1978) pointed out that there the dyke density was considerably lower that might be expected were the proposal correct. A more compelling case was made by Oliver \& McAlpine (1998) for a large block enclosed within the southern serpentinite at Duniewick Fort, on the north side of Knockdolian 
(Figure 2). They describe multiple parallel to sub-parallel dolerite dykes with asymmetric chilled margins and geochemistry compatible with eruption in a back arc environment. Oliver \& McAlpine note that from the evidence of this outcrop it would seem that parts of the original ophiolite sequence have been dismembered and incorporated into a serpentinite mélange.

The Craighead Inlier

About $7 \mathrm{~km}$ north-east of Girvan, the Craighead Inlier (Figure 1b) contains a volcanic assemblage of basaltic pillow lavas and associated bedded chert. The latter might have been coeval with the pillow lavas but might also have been a younger unconformable cover subsequently infolded with them. The lavas are commonly assumed to form the northern exposed extremity of the Ballantrae Complex, but the cherts have yielded conodonts (Lamont \& Lindström 1957) that in modern terms can be assigned to the anserinus and/or serra conodont biozones (Bergström 1971) of Late Llanvirn to earliest Caradoc age. So, depending on the exact relationship of the cherts with the lavas, it is possible that the latter are younger than those of the Ballantrae Complex sensu stricto. In that case the Craighead lavas would be postobduction eruptives, perhaps linked to some of the post-obduction intrusions seen within the main outcrop of the Ballantrae Complex (and discussed in the section below) although still a little on the young side even for that association.

\section{Intrusive gabbro and granite}

Coarse-grained intrusive rocks are a widespread, minor component of the Ballantrae Complex and form substantial, composite bodies at three localities: between Byne Hill and Grey Hill in the north of the Northern Serpentinite Belt, and around Millenderdale and north-east of Mains Hill, respectively at the north and south extremities of the Southern Serpentinite Belt (Figures 1c and 2). At Byne Hill, an intrusive body ranges in composition from a leucotonalite core, through dioritic lithologies, to gabbro at the margins that is chilled against the host northern serpentinite (Bloxam 1968). Zircons from the leucotonalite (often referred to as trondhjemite or plagiogranite) have provided a U-Pb cooling age of $483 \pm 4 \mathrm{Ma}$ (Bluck et al. 1980), but despite the similarity in age, the relationship of the Byne Hill - Grey 
Hill intrusion to the rest of the Ballantrae Complex is uncertain. The geochemistry of the gabbro and leucotonalite (Jelínek et al. 1984; Smellie \& Stone, 2001) suggests an origin in association with magmatism in an extensional, mid-ocean ridge setting but with an additional supra-subduction influence, whilst the field relationships are more indicative of post-obduction intrusion. At Millenderdale (Figures 1c and 2), gabbro bodies are banded and foliated - much more so than any of the other gabbroic bodies - and are cut by several generations of doleritic dykes, the earlier of which are themselves foliated (Jelínek et al. 1980); Bluck et al. (1980) reported a K-Ar age of $487 \pm 8 \mathrm{Ma}$ from a flaser gabbro from Millenderdale. Most of the dykes and parts of the gabbro bodies have been subjected to high-temperature metamorphic recrystallisation and are now granular-textured metamorphic rocks known as beerbachites (sensu Bloxam 1955; Jelínek et al. 1980) which are discussed in more detail below. The relationship of the Millenderdale rocks to the rest of the Ballantrae Complex remains conjectural. Their geochemistry suggested to Jelínek et al (1980) an origin at a mid-ocean spreading ridge - and the Millenderdale dykes had been tentatively identified as a potential sheeted dyke example by Church \& Gayer (1973) - but Smellie \& Stone (2001) thought that an origin in association with ocean island (within-plate) magmatism was more likely. Within the southern serpentinite, foliated and metamorphosed doleritic rock (beerbachite s.l.) forms a multitude of small enclaves that may be the remains of disrupted dykes.

Several small gabbro bodies are intruded into the southern serpentinite in the vicinity of Mains Hill (Figure 1c). They do not show unusually intense metamorphic effects and some have margins that are chilled against the host ultramafic rock, though the largest gabbroic mass in this part of the complex appears to have entirely faulted margins. These gabbros may be post-obduction intrusions, as are numerous small dolerite and gabbro bodies in the central part of the Ballantrae Complex, between Knockdaw Hill and Balsalloch (Figure 5). There, both serpentinite and Balcreuchan Group lavas have been intruded, whilst on the north side of Carleton Hill (the northeast spur of Balsalloch Hill) intrusive dolerite sheets cut across the metamorphic zone at the base of the northern serpentinite (Holub et al. 1984). None of the postobduction intrusions cuts the Llanvirn and younger sedimentary succession that overlies the Ballantrae Complex, restricting their likely age to the upper Arenig or very earliest Llanvirn. 


\section{Metamorphic rocks}

Nearly all of the rocks of the Ballantrae Complex have experienced some degree of metamorphism. The basalt lava assemblages have been largely spilitised (an oceanfloor process involving Na-metasomatism) and show evidence of burial metamorphism within either the prehnite-pumpellyite or zeolite facies (Smellie 1984b). Low values for the colour alteration index of conodonts from the sedimentary cover sequence to the ophiolite (Bergström 1980) suggest a depth of burial not much in excess of $3 \mathrm{~km}$.

The serpentinisation of the ultramafic components of the complex would seem to have been a post-obduction effect since the Ballantrae serpentinites are characterised by pseudomorphic mesh textures indicative of essentially stress-free recrystallisation. Lizardite and chrysotile are the predominant serpentine minerals, suggesting an upper temperature limit of about $350^{\circ} \mathrm{C}$ for the alteration, though a second, higher temperature phase of recrystallisation may have occurred locally with the development of antigoritic textures (Stone et al. 1984; Stone \& Smellie 1988). Cametasomatism was a widespread phenomenon accompanying serpentinisation, transforming rocks adjacent to the serpentinite bodies into a grey, flinty lithology known as rodingite (Bloxam 1954), which contains abundant Ca-rich secondary minerals (prehnite, pectolite, hydrogarnet etc). An associated process was the development of 'ophicarbonate' at the margins of the serpentinite bodies by the replacement of the original mafic minerals by carbonate (usually dolomite) and quartz, accompanied by polyphase carbonate-quartz veining (Stone \& Smellie 1988). The widespread presence of accessory chrome spinel in the 'ophicarbonate' (sometimes referred to as listwaenite) confirms the ultramafic nature of its protolith.

The various higher-grade metamorphic rocks incorporated into the Ballantrae Complex include some of its least-well understood components. They can be conveniently considered in four categories: dynamothermal aureole rocks, mantle segregations, blueschists and beerbachites.

The dynamothermal 'metamorphic sole' 
The schistose rocks forming a narrow zone along the south-east margin of the Northern Serpentinite Belt at its contact with volcanic rocks (Figure 5) were noted by Peach \& Horne (1899) and related by Anderson (1936) to shearing at the margin of a supposed serpentinite intrusion. Bloxam (1955) envisaged the metamorphic lithologies being incorporated during dilational rise of the serpentinite, an interpretation approaching more recent proposals of serpentinite diapirism in other ophiolitic settings. Church \& Gayer (1973), developing the ophiolitic model, likened the schistose zone to a metamorphic sole formed at the base of a hot slab of mantle ultramafic rock during thrusting initiated deep within oceanic lithosphere and ending with the obduction of the ophiolite complex.

The serpentinite close to the faulted south-east margin of the Northern Belt carries a tectonic foliation that is roughly parallel to the boundary fault. As exposed in the Knocklaugh Bridge area (but not necessarily elsewhere) a foliated garnet-bearing metapyroxenite forms the outer extremity of the ultramafic belt. It is in faulted contact with schistose garnet amphibolite that grades sequentially into plagioclaseamphibolite, epidote schist and then greenschist-facies rocks farther from the contact (Bluck 1978; Bloxam 1980; Spray \& Williams 1980; Treloar et al. 1980). The amphibolites and other schistose rocks have been derived from basalts, possibly with some original sedimentary interbeds. Conditions of formation for the garnetmetapyroxenite have been estimated at about $900^{\circ} \mathrm{C}$ and $10-11 \mathrm{~kb}$ (Treloar et al. 1980) with lower values of $850^{\circ} \mathrm{C}$ and $7 \mathrm{~kb}$ derived for part of the adjacent amphibolite development (Spray \& Williams 1980). Still lower pressure and temperature conditions would have prevailed during the formation of the lower grade schists. The 'metamorphic sole' assemblage is everywhere less than $100 \mathrm{~m}$ thick, mostly nearer $50 \mathrm{~m}$, so that the pressure and temperature gradients recorded by the rocks have clearly been structurally attenuated during what was most probably polyphase deformation (Spray \& Williams 1980). This remains true whether the garnet-metapyroxenite is regarded as a part of the metamorphic sole or as an original pyroxenite enclave within Northern Serpentinite Belt.

The garnet-metapyroxenite has been dated (Sm-Nd) at 505 11 Ma (Hamilton et al. 1984 ) and the amphibolite (K-Ar) at $478 \pm 8 \mathrm{Ma}$ (Bluck et al. 1980). The difference in 
these ages may reflect the rise of the ultramafic slab and the sequential accretion at its base of progressively lower-grade metamorphic lithologies. However, it is not certain that the ca 505 Ma metapyroxenite formed as part of the metamorphic event. Such an origin is preferred by Treloar et al. (1980) and has been carried forward by Bluck (in Oliver et al. 2002). An alternative view developed by Spray (1982), and preferred by Smellie \& Stone (1984), regarded the metapyroxenite as essentially a mantle segregation caught-up in the metamorphic aureole.

\section{Mantle segregations}

Whatever the origin of the ca 505 Ma metapyroxenite from the metamorphic aureole at Knocklaugh (above) the similar, unusual 'eclogite' lithology found at Knockormal (Figure 5) has also received much attention. This hornblende-garnet clinopyroxenite, originally described by Balsillie (1937), has been variously interpreted as: a relic ultramafic lens within serpentinised harzburgite (Bloxam \& Allen 1960), a tectonically isolated fragment of a disrupted metamorphic aureole (Spray \& Williams 1980; Treloar et al. 1980), or an exotic clast within (or derived from) either a sedimentary mélange or olistostrome (Church \& Gayer 1973) or a serpentinite-hosted mélange (Kawai et al. 2008). Similar lithologies are certainly present in the sedimentary mélange exposed at Pinbain Bridge (Bailey \& McCallien 1957). The early work on the Knockormal 'eclogite' was based on loose material, but very similar, in situ garnet-pyroxenite discovered nearby in a temporary trench was described by Smellie \& Stone (1984) as containing tschermakitic hornblende, fassaitic clinopyroxene and almandine-rich pyrope. This paragenesis was thought to be most consistent with an origin in the lowermost crust or upper mantle at a pressure between 10 and $13 \mathrm{~kb}$ and a temperature of about $900-950^{\circ} \mathrm{C}$, conditions very similar to those deduced for the Knocklaugh metapyroxenite by Treloar et al. (1980) and not compatible with the eclogite facies. Smellie \& Stone (1984) suggested that both examples originated as mantle segregations in serpentinised harzburgite, possibly formed as partial melts during the diapiric rise of mantle lherzolite with harzburgite left as a residuum.

\section{Blueschist}


Fragments of glaucophane- and crossite-bearing schistose rocks, some additionally containing garnet, are found in sedimentary mélange deposits at Pinbain Bridge, adjacent to the north-west margin of the Northern Serpentinite Belt (Bailey \& McCallien 1957), and at several localities inland adjacent to that belt's south-east margin (Balsillie 1937; Bloxam 1980; Smellie 1984b). Kawai et al. (2008) presume that the mélange host is serpentinite, but this is demonstrably not the case. The age of these blueschists is uncertain but would seem to be pre-Arenig. At Pinbain Bridge, the host mélange deposit is adjacent to, but structurally isolated from, a sequence from which early Arenig graptolites have been recovered (Rushton et al. 1986). Some of the inland blueschist occurrences are in mélange deposits that seem to be part of sedimentary assemblages similar to the one seen at Pinbain, but which lack the biostratigraphical control found there. If a pre-Arenig age is accepted, it would suggest that some parts of a pre-existing subduction complex, the most likely source of blueschist, had been exhumed and eroded prior to the development of the Ballantrae Complex sensu stricto. Noting this, Bloxam (1980) concluded that the original proposal of a Precambrian age by Balsillie (1937) may be apposite, with blueschist blocks "caught-up in the serpentinite during its cold diapiric rise and tectonic emplacement".

Much the same process of cold diapirism was invoked in the recent interpretation by Kawai et al. (2008) of the loose blocks and in-situ outcrops of blue-amphibolebearing schistose basalt that occur at Knockormal (Balsillie 1937; Bloxam \& Allen 1960), close to the 'eclogite' locality (see above). The proximity of the 'exotic' lithologies has encouraged their joint inclusion in a putative mélange, with either a sedimentary matrix (Church \& Gayer 1973) or serpentinite matrix (Bloxam 1980; Kawai et al. 2008), though the field evidence is ambiguous at best and these rocks remain enigmatic.

\section{Beerbachite}

Within both serpentinite belts, but most widely in the southern one, tectonic inclusions of gabbro and dolerite have been variably metamorphosed under hornblende- and pyroxene-hornfels conditions (Balsillie 1932, 1937); the higher grade examples display foliated and/or granoblastic textures. These rocks were termed 
'beerbachites' by Bloxam (1955) who thought them to have been engulfed and thermally metamorphosed by intrusive peridotite magma, although later (Bloxam 1980) he stressed their lithological similarity to some of the amphibolites within the dynamothermal aureole. Jelínek et al. (1980) estimated the metamorphic temperature at $900-1000^{\circ} \mathrm{C}$. They envisaged such conditions in an ocean-ridge, spreading environment where doleritic ocean crust was transported within a transform fault so that it experienced prolonged juxtaposition to the high-heat flow environment of the spreading centre. Subsequent disruption of the metamorphosed dolerite body would still be required and this may have occurred during 'cold' diapiric emplacement of the serpentinite, with consequential incorporation of the meta-dolerites as tectonic inclusions.

\section{Origins and emplacement of the Complex}

As a precursor to considering the development models for the Ballantrae Complex, it is appropriate to summarise the age control that pertains, but three cautionary notes are needed. Firstly, most of the available radiometric ages were published thirty or more years ago and may very well be revised by current analytical techniques. Secondly, most of the published ages have relatively large errors that, in some cases, are perhaps sufficient to question the veracity of the analysis; undoubtedly the most precise age control is provided by the graptolites found in sedimentary interbeds within some of the lava successions. Thirdly, the ages derived from different isotopic systems with different mineral (or whole-rock) targets, may not be directly comparable since they may not be dating the same stage in the cooling process. Subject to those reservations, most of the published results for the Ballantrae Complex are shown in Figure 7; the time scale used follows Gradstein et al. (2012).

The hornblende-garnet clinopyroxenite from Knockormal dated (Sm-Nd) at $576 \pm 32$ Ma (Hamilton et al. 1984) is enigmatic and is not included in Figure 7. The break-up of Rodinia to form the Iapetus Ocean commenced at about 590-600 Ma so if the pyroxenite originated as a mantle segregation as preferred by Smellie \& Stone (1984) then it must be a relic from the early days of the ocean and might suggest that more of the Ballantrae ultramafic rock is similarly ancient. Alternatively, if the Knockormal pyroxenite is an isolated block in a sediment-hosted mélange, then it suggests an 
episode of mantle uplift and erosion prior to formation of the Ballantrae Complex, during an interval when the Laurentian margin of Iapetus was apparently passive (Bluck in Oliver et al. 2002). It is worth remembering that Bluck (1978, 1983, 2001) has consistently argued that more than one accretion/obduction event has contributed to the development of the Ballantrae Complex, as considered in more detail below. Assuming a Knockormal mélange to be serpentinite-hosted, Kawai et al. (2008) relate its origin to serpentinite diapirism and see the pyroxenite as an exotic mantle relic.

A late Cambrian to early Ordovician age has been established for eruption of the island arc volcanoes from radiometric (Sm-Nd) dating of their basalts at $501 \pm 12$ and $476 \pm 14 \mathrm{Ma}$ (Thirlwall \& Bluck 1984). The gabbro at Byne Hill, in the north of the complex, has geochemical characteristics associated with supra-subduction zone intrusion (Smellie \& Stone 2001) and is intimately associated with the leucotonalite dated (U-Pb) at $483 \pm 4 \mathrm{Ma}$ (Bluck et al. 1980). The age of the within-plate components overlaps this range. The sedimentary strata interbedded with the basalt lavas contain early Arenig (Floian, 471-478 Ma: Figure 7) graptolite faunas, whilst zircons from tuff interbeds at Bennane Head have been dated (U-Pb) at $470 \pm 10 \mathrm{Ma}$ (Sawaki et al. 2010). The Millenderdale gabbro is also thought to have had a withinplate origin (Smellie \& Stone 2001) and has been dated (K-Ar) at $487 \pm 8 \mathrm{Ma}$ (Bluck et al. 1980). Not included in Figure 7 is the first radiometric date recorded from the Ballantrae Complex: ca $475 \mathrm{Ma}, \mathrm{K}-\mathrm{Ar}$ from biotite in a gabbro " 1.5 miles north of Colmonell" (Harris et al. 1965). This poorly defined location probably relates to a gabbroic enclave within the Southern Serpentinite Belt that might be either intrusive or a tectonic inclusion related to the beerbachite bodies.

It is clear that the Ballantrae Complex ophiolite was finally emplaced onto or against the Midland Valley continental basement, at that time the leading edge of Laurentia, during the middle to late Arenig. Relatively high-grade metamorphic rocks were formed during a phase of obduction (not necessarily the final event) as hot mantle material was thrust up and across the basalt lavas of the oceanic crust. These are now seen as the metamorphic sole at the base (the south-east margin) of the northern serpentinite, in which a structurally condensed sequence only 40-100 m thick ranges from metapyroxenite dated (Sm-Nd) at $505 \pm 11 \mathrm{Ma}$ (Hamilton et al. 1984) to amphibolite dated (K-Ar) at $478 \pm 8 \mathrm{Ma}$ (Bluck et al. 1980). It is not certain that the 
metapyroxenite age relates to obduction since it may possibly have formed as a mantle segregation (Smellie \& Stone 1984), but the amphibolite age is generally thought to record its progress. Late Arenig (468 Ma: Figure 7) sedimentary rocks (Stone \& Strachan 1981) that were probably deposited during the obduction process are now structurally included within the complex (Stone \& Rushton 2003), whilst the oldest strata within the unconformably overlying cover sequence (comprising the Barr Group) are of early Llanvirn age (Williams 1962).

In a broad, regional context, the obduction of the Ballantrae Complex would seem to be part of the large-scale and multi-element, arc-continent collision that culminated, around $470 \mathrm{Ma}$, in the Grampian Event of the Caledonian Orogeny. The series of cartoons in Figure 8 is an attempt to show the relationship of the events that constructed the Ballantrae Complex to the larger-scale tectonic processes that closed the Iapetus Ocean and consolidated the terranes of southern Scotland. A useful comparison is provided by Oliver (2002, figure 7.5).

Arcs, back-arcs and ocean islands

There is general agreement that the Ballantrae Complex is an assemblage of polygenetic, oceanic rocks, most of which originated either in one or more island arcs (or their back-arc zones) or at within-plate volcanic centres. There is less of a consensus as to how the various components were brought together and what tectonic processes were responsible. The generalized, arc and marginal basin proposal of Dewey (1971) and Church \& Gayer (1973) was refined with local detail by Bluck (1978), and tested by a succession of studies concentrating on the geochemistry of the lava successions. The first such study, by Wilkinson \& Cann (1974), showed a surprising level of heterogeneity within the complex and was followed by others that produced seemingly contradictory results (e.g. Lewis \& Bloxam 1977) or suggested that the Ballantrae lavas had suffered high levels of crustal contamination, rendering unreliable the geochemical discrimination of eruption environment (e.g. Jelínek et al. 1980). This phase of research has been summarised by Thirlwall \& Bluck (1984), who demonstrated unequivocally that the complex was indeed polygenetic.

Thereafter, as analytical techniques improved, the wide range of arc, BABB-like and within-plate rocks present was firmly established and incorporated into an inclusive 
model of volcanic arcs and a back arc spreading zone (Stone \& Smellie 1990; Smellie \& Stone 1992, 2001; Smellie et al. 1995). Some geochemical signatures are more definitive than others, and so the discovery of boninites amongst the Games Loup arc lavas (Smellie et al. 1995) was regarded as particularly compelling evidence for the eruption of those lavas at a relatively primitive island arc. In contrast, the chemistry of the lavas forming the Mains Hill sequence was more indicative of eruption at a relatively mature island arc (Thirlwall \& Bluck 1984).

The ultramafic components of the Ballantrae Complex also show a degree of heterogeneity and at least a partial supra-subduction zone association. The detailed chemistry of rocks from both ultramafic belts, and also of the chrome spinel grains that they contain, is anomalous for normal ocean lithosphere and suggests that they formed in metasomatised mantle above a subduction zone (Stone \& Smellie 1990). However, subtle but significant differences in composition between the two main outcrops, the Northern and Southern Serpentinite belts, show that they do not share the same history of formation. The northern serpentinite is the more metasomatised of the two and most probably originated in a sub-arc environment. The southern serpentinite, though still metasomatised, has more of the characteristics of mid-ocean mantle.

The range and complexity of the geological components present in the Ballantrae Complex has been addressed in two different ways. Bluck (2001, and in Oliver et al. 2002) has envisaged a series of obduction/accretion events alternating with phases of renewed marginal basin extension and volcanism. Other authors have sought to accommodate all elements of the Ballantrae complex within a single, evolving arc back-arc basin; see for example Stone \& Smellie (1990) and Smellie \& Stone (2001), whose model of an early-formed arc split by back-arc spreading to accommodate a range of supra-subduction and within-plate components, is reproduced in simplified form in Figure 3 ( $a$ and $b$ ). More recently, a valid variation has been introduced by Kawai et al. (2008) who envisage that, following supra-subduction zone arc volcanism, ridge subduction and consequent slab break-off created a window in the descending oceanic crust. In this situation (Figure 3c) they point out that seemingly within-plate, OIB-like lavas can be erupted close to arc-generated lavas in both time and space. Under such circumstances the apparent interbedding of volcanogenic rocks 
showing properties of the two different geotectonic environments, as at Bennane Head and Pinbain Bridge, can be readily visualised. However, such an interpretation would require all of the Ballantrae OIB-type lavas to be of much the same age as the mature arc lavas, a relationship at odds with the available chronological evidence. Another alternative explanation introduced by Smellie \& Stone (2001) might be provided by the variety of lava types erupted during off-axis magmatism and the propagation of a spreading ridge into arc and back-arc crust (e.g. Falloon et al. 1992). Overall, and in view of the lithological complexity at Ballantrae, it is conceivable that many (perhaps all) of the proposed conditions pertained at different times.

Tectonic assembly of the complex

In Bluck's (2001) proposal for the polyphase generation of the Ballantrae Complex an 'accretion 1' event takes the ca $576 \mathrm{Ma}$, Neoproterozoic garnet-metapyroxenite age as indicating early subduction at the Laurentian margin, the products of which were caught-up in a subsequent marginal basin assemblage. In contrast, Smellie \& Stone (2001) see the metapyroxenite as a mantle segregation unrelated to subduction. Bluck's 'accretion 2' event, in the late Cambrian or earliest Ordovician, involved oceanic obduction of serpentinite across marginal basin volcanic rocks, prior to a renewal of marginal basin extension and volcanism through the early Arenig. This second marginal basin was then compressed and disrupted during an 'accretion 3' event by a combination of thrust and strike-slip tectonics prior to final obduction of the Complex onto the Laurentian continental margin at about $470 \mathrm{Ma}$, the late Arenig 'accretion 4' event.

The final, 'accretion 4' event envisaged by Bluck (2001) was subsequently combined by him with the 'accretion 3' event (Bluck in Oliver et al. 2002) but the overall process envisaged was northward thrust emplacement of the ophiolite prior to the development of a 'Midland Valley arc' above a north-directed subduction zone. To illustrate the thrust emplacement concept, the linear outcrop belts within the Ballantrae Complex have been envisaged by Armstrong et al. (1999, fig. 2) as southdipping thrust 'horses' carried northwards, over the Midland Valley Terrane, on a major sole thrust. Evidence for the subsequent 'Midland Valley arc' comes from dated igneous detritus believed to have been eroded from it and which is now 
contained in Upper Ordovician conglomerates and Silurian sandstones in the Midland Valley terrane and adjacent parts of the Southern Uplands accretionary complex. Granitoid boulders in conglomerates, derived from the north, that unconformably overlie the Ballantrae ophiolite have Rb-Sr ages in the range $459 \pm 10 \mathrm{Ma}$ to $471 \pm 13$ $\mathrm{Ma}$ (Longman et al. 1979) and U-Pb zircon ages from Silurian sandstones of the Midland Valley terrane show a distribution peak at about $475 \mathrm{Ma}$ (Phillips et al. 2009). A granitoid boulder in a conglomerate derived from the north within the northern part of the Southern Uplands terrane has given a U-Pb monazite age of $474 \pm 2 \mathrm{Ma}$ (Bluck et al. 2006), but this is considered to be most probably the age of the metamorphic xenoliths from which the monazite was derived, rather than the age of the igneous host rock. Accordingly, Bluck et al. deduced intrusion to have taken place between $474 \pm 2 \mathrm{Ma}$ and ca $458 \mathrm{Ma}$, the latter being the depositional age of the deposit in which the boulder was found.

A common feature of the two oceanic arc models shown in Figure 3, which seek to accommodate all of the Ballantrae Complex elements within a single arc-related environment, is the southward direction of subduction. In large part this was assumed by the authors as a convenient facilitator of arc-continent collision, which was followed by a late Arenig, immediately post-collision reversal in the subduction polarity to northward, so accommodating the evidence for arc magmatism in the Midland Valley. This concept has long featured in Caledonian tectonic reconstructions (e.g. Mitchell 1978). Sawaki et al. (2010) cite structural evidence from the Bennane Head area of the Ballantrae Complex in support of southward subduction during its formation, but their evidence seems weak in the light of the multiple deformations to which the area has been subjected, and the absence of any correction in their analysis for the locally steep plunge of fold hinges.

An ingenious test of the subduction direction during development of the Ballantrae arc to back-arc assemblage was presented by Armstrong et al. (1999) based on the rare earth geochemistry of cherts from the Balcreuchan Group outcrop at Bennane Lea. They reasoned that, because the cherts from the Ballantrae Complex would inherit a geochemical signature from their environment of origin, they could be used to test the models arising from either north-directed or south-directed subduction. If subduction was north-directed, the cherts would have formed in a back-arc basin 
contiguous to the continental margin, and so would be expected to inherit some terrestrial character. In contrast, if subduction was south-directed, the cherts would have been deposited in a basin separated from the continental margin by a trench, which would have effectively isolated them from any terrestrial input. From the composition of the Bennane Lea cherts, Armstrong et al. deduced a terrestrial input and so favoured their formation, together with the rest of the Ballantrae Complex, in a rifted basin above a north-dipping subduction zone, albeit one that was still entirely oceanic. One weakness of this interpretation might lie in the age of the sampled cherts at Bennane Lea. They are of likely Chewtonian age (Figure 7b: Locality 5 from Stone \& Rushton, 1983) and so formed relatively late in the overall development of the Complex. By that time, arc-continent collision would have been incipient, and any physical barriers to a terrestrial input may have broken down. Nevertheless, the concept of a terrestrial input arising from south-directed subduction might also be applied to the lava geochemistry. Since that is exclusively oceanic, with no indication of any terrestrial contamination, it could also be cited in support of north-directed subduction.

The importance of tectonics driven by arc-continent collision in assembly of the Ballantrae Complex is reduced in the model of Kawai et al. (2008) which invokes serpentinite diapirism as a major mechanism: "We speculate that a serpentinite diapir brought the high-pressure metamorphic rocks to the surface ... [and that] ... doming was most likely caused by southward underthrusting of Dalradian sediments from the north at the toe of the accretionary wedge" (Kawai et al. 2008, p. 352). Diapirism has been previously introduced in a general sense as a means of bringing metamorphic rocks to a higher structural level (e.g. Church \& Gayer 1973) or to incorporate blocks of a dismembered sheeted dyke complex into serpentinite (Oliver \& McAlpine 1998), but the circumstances that Kawai et al. speculate to have caused it seem unlikely. Their interpretation, by extending Dalradian and Moine rocks beneath the Midland Valley (and even the northern part of the Southern Uplands terrane), to impinge on an Iapetus oceanic subduction zone, ignores the presence of a separate Midland Valley continental block, now a well established feature of Scottish geology (e.g. Bluck 1984, 2001). Even so, Kawai et al. still envisage a switch from south-directed to north-directed subduction coincident with obduction of the ophiolitic rocks. 
It can be argued, though not proved, that the tectonic juxtaposition of the various different parts of the complex would be facilitated if significant strike-slip movement occurred during collision of the arc with the Laurentian continental margin (Stone 1984). Taken to its limits, this process could assemble the Ballantrae ophiolite as a series of strike-slip, lateral duplexes in a steeply inclined shear zone, rather than as a series of thrust sheets obducted northwards. How much of the Midland Valley basement was overthrust by ophiolite bodies has long been a matter of conjecture, with a relatively wide expanse along the southern margin, effectively an extension of the Ballantrae Complex now covered by younger rocks, being commonly favoured (e.g. Bluck 2001, fig. 17) and arguably supported by the presence of ophiolitic material as xenoliths in Carboniferous volcanic vents to the north of Girvan (Whyte 1964). However, geophysical evidence seems to be less indicative of a widespread ophiolitic presence at depth. Instead, gravity and magnetic modelling (Kimbell \& Stone 1995; British Geological Survey 2006) shows the Ballantrae Complex to have a steeply inclined extension for at least $30 \mathrm{~km}$ along strike to the north-east, in a narrow zone adjacent to the north side of the Stinchar Valley - Southern Upland Fault and buried beneath younger rocks (Figure 4, section A-B). This narrow zone of ophiolitic rocks extends downwards to a depth of about 6 or $7 \mathrm{~km}$ and appears to separate broadly similar basement blocks most probably composed of metamorphosed Lower Palaeozoic rocks. To the south, these would be steeply inclined Ordovician strata within the deeper part of the Southern Uplands accretionary complex; the nature of the unit to the north, within the concealed Midland Valley 'basement', is unknown.

A comparable picture emerges from the more detailed data covering the Ballantrae Complex outcrop. There, aeromagnetic data over the Northern Serpentinite Belt show a marked positive anomaly which, coupled with a negative gravity anomaly, suggests a substantial depth extent for that ultramafic body. In contrast, the Southern Serpentinite Belt is only weakly defined magnetically, and coincides very approximately with a gravity high, features that suggest it has no significant deep continuation, a possibility first demonstrated by Powell et al. (1978). Immediately to the east of the Ballantrae Complex outcrop, its buried continuation has been modelled by Kimbell (in Floyd 1999) as a steep sided block extending to a depth of about 2.5 km (Figure 4, section C-D). It should be noted that the Ballantrae Complex contributes only part of this anomaly, the southern part being associated with the 
outcrop of the Dalreoch Formation, a lithostratigraphical unit of Early Caradoc (Sandbian) wacke sandstones that contain much ophiolitic and volcaniclastic detritus and, accordingly, have a relatively high magnetic susceptibility (Floyd 1999). The Dalreoch Formation (part of the Tappins Group) was one of the earliest accreted tracts in the Southern Uplands accretionary complex and is separated from the Ballantrae Complex by the Stinchar Valley Fault, the local expression of the Southern Upland Fault which, on a regional scale, separates the Midland Valley and Southern Uplands terranes. It is possible that the magnetic anomaly farther to the north-east modelled by Kimbell \& Stone (1995) as the result of a buried extension of the Ballantrae Complex (Figure 4, section A-B), also arises in part from Tappins Group rocks. However, the Southern Upland Fault as currently mapped lies to the south-east of that magnetic anomaly, making an association with the Ballantrae Complex the more likely interpretation.

Taken together, the detailed geophysical data for the Ballantrae Complex outcrop and the regional data demonstrating its along-strike extension, show a substantial but steeply inclined ophiolitic body extending to depths up to about $7 \mathrm{~km}$ and for at least $30 \mathrm{~km}$ along strike, but with a cross-strike width of less than $10 \mathrm{~km}$; see British Geological Survey (2006) for details, summarised in Stone et al. (2012, fig. 7). This geometry is perhaps more in keeping with accretion of the ophiolitic rocks within a major strike-slip zone at the margin of Laurentia, than it is with their obduction as thrust sheets onto that continental margin. The apparent presence of dense, metamorphosed Lower Palaeozoic basement underlying the Southern Uplands accretionary complex but immediately to the south of the ophiolitic zone at depth may be significant. It reinforces a picture of the Ballantrae Complex as the surface expression of an ophiolitic 'root' extending to depth within a major fault zone, rather than forming part of a once more extensive ophiolite sheet thrust onto the continental margin, albeit there is no clear evidence for displacement of the sub-ophiolite basement at the margins of the complex.

The principal problem with this interpretation is, of course, that in terms of the deeper structure, the Southern Upland Fault does not coincide with the southern margin of Laurentia. Crystalline basement of non-magnetic, 'Midland-Valley-type' appears to lie beneath the Ballantrae Complex and extends southward beyond the Southern 
Upland Fault, to underlie the Southern Uplands accretionary complex at least as far as the Orlock Bridge Fault (Figure 4, section A-B). The southern part of the accretionary complex, south of the Orlock Bridge Fault appears to overlie magnetic crystalline basement of peri-Gondwanan type trapped in the hanging wall of what is universally regarded as the Iapetus Suture (Kimbell \& Stone 1995). If the Ballantrae Complex arose as oceanic crust in the Iapetus Ocean, considerable northward displacement must have occurred during obduction. Alternatively, the Ballantrae Complex might be a fortuitously preserved oceanic fragment, trapped during the accretion of a series of microcontinental slivers at the Laurentian margin. Essentially this is a restatement of a long-standing (and unresolved) concern first rehearsed by Bluck (1985).

One line of evidence that would seem to unequivocally support the obduction model is of course the existence of the metamorphic sole at the base of the Northern Serpentinite Belt. But even so, major problems of timing remain. The thrusting of hot, mantle ultramafic rock through and across the crustal sequences has been radiometrically dated, possibly as early at $505 \pm 11$ Ma and more definitively at $478 \pm 8$ Ma. If both dates apply, they suggest that the obduction process was either polyphase (Spray \& Williams 1980) and probably protracted, a view reinforced by Bluck (2001, and in Oliver et al. 2002). There was certainly continuing, post-obduction igneous development of the complex since ultramafic rock has been intruded by gabbro and leucotonalite, at Byne Hill for example. There, the igneous bodies have chilled margins, demonstrating that the host serpentinite had cooled by the time of intrusion, $482 \pm 5 \mathrm{Ma}$ in the case of the leucotonalite. Elsewhere, north-east of Balsalloch Hill, the dynamothermal metamorphic aureole is cut by dolerite dykes that do not penetrate the Llanvirn and younger sedimentary cover, so constraining magmatism to the late Arenig (Holub et al. 1984; Stone \& Smellie 1988).

Taking the radiometric dates at face value, there would appear to be an overlap between the production of the metamorphic aureole by the emplacement of hot ultramafic rock at $478 \pm 8 \mathrm{Ma}$ but the intrusion of leucotonalite and gabbro at $482 \pm 5$ Ma into cool ultramafic rock (hence the chilled margins of the gabbro). The two sets of data come from adjacent areas of the Northern Serpentinite Belt and suggest that the later stages of the complex's development were of short duration. That message is reinforced by the appearance in sedimentary mélange deposits, themselves intimately 
associated with the Balcreuchan Group and of probable Early Arenig age, of amphibolite schist clasts probably derived from the dynamothermal aureole. The mélange deposits also contain a range of volcanic and intrusive rock types, probably sourced locally during the final stages of tectonic assembly of the complex, as well as more exotic lithologies including blue-amphibole schists. The latter were formed at considerable depth and were most likely derived from a pre-existing subduction complex; it would be of great interest to discover their age.

The youngest strata known to be associated with the Ballantrae Complex form a clastic sequence known only from a borehole at North Ballaird (Figure 1c) that contains a Late Arenig (ca 468.5 Ma, Figure 7) graptolite fauna (Stone \& Strachan 1981; Stone \& Rushton 2003; Maletz 2004). All of its margins appear to be faulted against parts of the Balcreuchan Group. Granules of altered serpentinite in one of the Late Arenig beds have algal rims, demonstrating that mantle-derived, ultramafic rock was available for erosion into shallow water by the late Arenig (Stone 1982; Stone \& Smellie 1988). This presumably marks the final stage of obduction and tectonic assembly, processes that were essentially complete by the early Llanvirn (ca $465 \mathrm{Ma}$ ) when the lowest beds of the unconformable sedimentary cover sequence were deposited. The detail of the obduction-related structure is difficult to decipher and has most probably been further complicated by subsequent tectonic events. Some indication of the overall structural complexity is shown by the tectonic repetition, perhaps a syn-obduction effect, of the graptolitic mudstone-chert-lava succession between Bennane Head and Balcreuchan Port (Stone \& Rushton 1983).

Post-obduction episodes of deformation must also be taken into account in any assessment of the internal structure of the Ballantrae Complex. The Ordovician to Silurian cover sequence to the ophiolite accumulated in a forearc basin to the south of the Midland Valley volcanic arc, then being uplifted. Deposition in the forearc basin was controlled by a series of major faults, throwing down to the south and sequentially stepping back into the Laurentian hinterland (Williams 1962; Ince 1984). As a result, the earliest strata of the cover sequence become progressively younger northwards, from early Llanvirn in the valley of the River Stinchar, to late Caradoc in the Craighead Inlier (Figure 1b), albeit the presence of Late Llanvirn or earliest Caradoc cherts in association with the lavas at Craighead (Figure 7) is a complicating 
factor that does not sit easily with the regional model. Irrespective of that difficulty, there would undoubtedly have been some rotation of the early-deposited beds, and parts of the underlying ophiolite assemblage, during the fault growth and migration that controlled the overall (and unequivocal) transgression, but there is only one stratigraphical break preserved in the Girvan cover sequence. This coincides, approximately, with the Ordovician-Silurian boundary where the basal Silurian strata overlie the Ordovician at an unconformity with low-angle structural discordance.

The major structural disruption occurred in the mid to late Silurian, when the faults that had controlled sedimentation were re-activated as north-directed thrusts (Williams 1962). The cause of this reversal is uncertain, but was most probably related to the encroachment, farther south, of the leading edge of the Southern Uplands accretionary complex onto the northern margin of the peri-Gondwana, Avalonia terrane. As collision proceeded, shortening within the accretionary complex (by the widespread rotation of bedding to the near-vertical) may well have been accompanied by its large-scale northward thrusting onto the Laurentian margin. In turn, in the Girvan district, the normal faults that had controlled deposition of the Ordovician to Silurian forearc basin succession were reactivated as north-directed thrusts with adjacent strata rotated and folded so that steep dips are now commonly seen at outcrop. The thrust re-activation could have begun quite early in the Wenlock since the youngest strata affected (and now preserved) are of earliest Wenlock age (Cocks \& Toghill 1973; Floyd \& Williams 2003).

However, when associating structural events in the Southern Uplands accretionary complex with those at Ballantrae, a note of caution must be added. Though the overall association of geological regimes fits the present-day outcrop pattern, it is highly unlikely that the original spatial relationships are preserved. The arc, foreland basin and accretionary complex all extended for considerable distances along strike, and substantial, sinistral strike-slip movement, post-Ordovician and particularly focused on the Southern Upland Fault, has brought about the juxtaposition currently seen. Further, as emphasised by Bluck (1984, 2001 and in Oliver et al. 2002) a considerable expanse of the Girvan forearc is missing, and there may well have been little connection between the currently juxtaposed geological terrane elements until the Devonian. Thereafter, Devonian transcurrent tectonics would have affected the 
Ballantrae Complex, as might have the extensional and basin inversion events of the Carboniferous; the Stinchar Valley - Southern Upland Fault was certainly reactivated at these times. Perhaps in association with reactivation of the Stinchar Valley Fault was the development of the parallel structure within the Southern Serpentinite Belt that has introduced down-faulted slices of the sedimentary cover sequence into the ultramafic rock to the north of Knockdolian (British Geological Survey 1988).

It is appropriate to conclude this section on a cautionary note. A considerable range of uncertainties currently clouds any overall interpretation of the tectonic assembly of the Ballantrae Complex. Future work will hopefully clarify the situation, and this account is most unlikely to be the final word on the matter.

\section{Regional correlations}

The Ballantrae Complex is one of a number of ophiolitic assemblages tracing the vestiges of the Iapetus Ocean within the Caledonian Orogen from Norway in the north-east to Newfoundland and beyond in the south-west. In Scotland examples are seen in the Shetland Islands of Unst and Fetlar, as faulted enclaves along the Highland Boundary Fault, and at Ballantrae, whilst farther south-west in Northern Ireland is the Tyrone Igneous Complex. Analogies have naturally been drawn between the Ballantrae Complex and the geographically proximal ophiolites of Tyrone and the Highland Boundary (Figure 1a), and these will be considered here; farther afield, there are similarities in age, structural position and development history with some of the Newfoundland ophiolites (e.g. Colman-Sadd et al. 1992).

\section{The Highland Border Complex}

Within the Highland Boundary Fault Zone, a series of structurally isolated, lenticular outcrops contain various combinations of serpentinite, basaltic pillow lava, black mudstone, chert, limestone and sandstone, apparently ranging in age from late Cambrian to late Ordovician. The oldest lithologies crop out on the island of Bute where serpentinite is associated with an amphibolite from which Chew et al. (2010) have obtained an age of $499 \pm 8 \mathrm{Ma}(\mathrm{U}-\mathrm{Pb})$ for magmatism and ages of $490 \pm 4 \mathrm{Ma}$ and $488 \pm 1 \mathrm{Ma}$ (both Ar-Ar) for the metamorphism, thought to be obduction-related. The 
volcanic and sedimentary components are apparently younger. All of these disparate elements are grouped together as the Highland Border Complex (HBC) (e.g. Robertson \& Henderson 1984; Curry et al. 1984). One view of the HBC sees it as the remains of a small, independent ocean basin that formed between the margin of the Laurentian continent and a separate continental block that now underpins the Midland Valley terrane (e.g. Bluck 1984, 2001, 2010). An alternative view has now linked most of the sedimentary rocks of the complex with the uppermost parts of the Dalradian succession in the adjacent Scottish Highlands (Tanner 1995; Tanner \& Sutherland 2007; Cawood et al. 2012), leaving mainly igneous rocks in an enigmatic Highland Border Complex. Even the superficially similar cherts found in several of the HBC outcrops prove, from the evidence of their rare-earth geochemistry, to have formed in markedly different geotectonic environments (Tanner et al. 2013).

Whatever the true division of the HBC rocks between the Dalradian and a Highland Border ophiolite, the generation and destruction of oceanic crust in the Highland Border basin was apparently in progress by about $500 \mathrm{Ma}$, with obduction-related metamorphism occurring at about $490 \mathrm{Ma}$ (Chew et al. 2010). Beyond their indicating broadly contemporaneous generation and destruction of oceanic crust, comparisons of the attenuated Highland Border Complex and the Ballantrae Complex seem tenuous at best. Implicit in some of the early plate tectonic models for the development of the Caledonian orogen was the possibility that the ophiolite complexes exposed at the north-west and south-east margins of the Midland Valley might be relics of an originally much more extensive, obducted ophiolite nappe (e.g. Dewey \& Shackleton 1984). This now seems unlikely.

\section{The Tyrone Igneous Complex}

The tectonic position of the Tyrone Igneous Complex is somewhat analogous to that of the Highland Border Complex, in that it is bounded by major fault zones and juxtaposed with rocks of the Dalradian Supergroup on its northern side. In addition, within the outcrop of the complex, the Tyrone Central Inlier comprises high-grade metamorphic rocks of probable Dalradian affinity (Chew et al. 2008). There are two structurally distinct parts to the Tyrone Igneous Complex, designated the Tyrone Plutonic Group (TPG) and the Tyrone Volcanic Group (TVG) (Cooper \& Mitchell 
2004). The TPG preserves the uppermost portion of a dismembered, supra-subduction zone ophiolite (Cooper et al. 2011) with layered, isotropic and pegmatitic gabbros, sheeted dolerite dykes and rare basaltic pillow lavas. U-Pb isotopic dates from the gabbros range approximately from $484 \mathrm{Ma}$ (Hollis et al. in press a) to $480 \mathrm{Ma}$ (Cooper et al. 2011), with obduction onto the Tyrone Central Inlier basement occurring prior to about $470 \mathrm{Ma}$. The latter date is constrained by the ages of postobduction intrusions that range between about $470 \mathrm{Ma}$ and $464 \mathrm{Ma}$, which contain xenocrystic Proterozoic zircons, and have strongly negative $\varepsilon N d t$ values (Draut et al. 2009; Cooper et al. 2011; Hollis et al. 2012).

The TVG is a variable, island arc to back-arc volcanic succession of lavas and other, mostly volcanogenic rocks, with compositions ranging from basaltic to rhyolitic (Hollis et al. 2012). In the lower part of the succession, basalts of arc, back-arc and within-plate affinity are dominant. All are interbedded with calc-alkaline, arc-derived volcaniclastic rocks that display strongly negative $\varepsilon N d t$ values. Lavas of island arc affinity are strongly calc-alkaline in the south-east of the TIC, but are dominantly tholeiitic and primitive in the north-east, where they are related to back-arc volcanism (Hollis et al. 2012). Lavas of within-plate affinity occur at several stratigraphical levels within the TVG and show Fe-Ti-P enrichment. A graptolite fauna of Castlemainian 1 age (Ca 1, Late Floian, ca 470 Ma: Figure 7) provides the only biostratigraphical constraint within the TVG (Cooper et al. 2008), whilst other isotopic dates from the upper part of the TVG range between about $473 \mathrm{Ma}$ and 469 Ma (Cooper et al. 2011; Hollis et al. 2012). The TVG lavas show evidence of contamination by continental material (Draut et al. 2009; Cooper et al. 2011) and are thought to have been erupted in a peri-Laurentian island-arc to back-arc environment, which underwent several episodes of intra-arc rifting (Hollis et al. 2012). Accretion to the outboard peri-Laurentian microcontinental block now represented by the Tyrone Central Inlier followed soon after obduction of the TPG, and was also complete by about $470 \mathrm{Ma}$.

Any comparison of the Tyrone and Ballantrae assemblages is hindered by the preservation of different ophiolitic components in each: gabbros, sheeted dykes and lavas dominate at Tyrone, ultramafic rocks and lavas at Ballantrae. Though the geochemical range of lava type and the ages from the ophiolite/arc at Tyrone are 
broadly similar to those from the Ballantrae Complex, there are also a number of significant differences. Perhaps most significant is the evidence for contamination by continental material at Tyrone, whereas the Ballantrae lavas are entirely oceanic and include arc-related boninitic varieties not seen at Tyrone. Conversely, the high Fe-Ti$\mathrm{P}$ lava types that are common at Tyrone do not seem to be present in the OIB successions at Ballantrae. Ages from the TPG overlap the broadly Tremadoc to Arenig ages from Ballantrae, though it should be acknowledged that most of the Ballantrae isotopic dates are relatively imprecise. Graptolite biostratigraphic ages from the Ballantrae Complex ophiolite sensu stricto are a little older than the one record from Tyrone, which was recovered from the Slieve Gallion area, a structurally isolated part of the TIG thought to correlate with a relatively low stratigraphical level within the TVG (Hollis et al. 2013b). If this correlation is correct, it means that the bulk of the TVG will be younger than the volcanic successions within the Ballantrae Complex. All of the Ballantrae faunas are associated with within-plate lava successions; the situation at Tyrone is less clear-cut, with the graptolite-bearing succession thought to correlate with a heterogeneous arc/back-arc succession that includes both island arc lavas of tholeiitic to calc-alkaline affinity and within-plate, OIB-type lavas (Hollis et al. 2013b).

The youngest fauna from Ballantrae (Ca4 to Ya1, see Figure 7) overlaps in age with the upper part of the TVG but is contained in a dominantly clastic sedimentary sequence thought to have been a post-volcanic, syn-obduction accumulation (Stone \& Rushton 2003). Post-obduction intrusions in both areas followed soon after obduction/accretion was complete. At Tyrone, intrusive bodies with U-Pb zircon ages ranging from about $470 \mathrm{Ma}$ to $464 \mathrm{Ma}$ cut the Tyrone Central Inlier basement and both parts of the structurally overlying Tyrone Igneous Complex (Cooper et al. 2011). In Scotland, the intrusions are represented only by boulders in Upper Ordovician conglomerates and detrital zircons in Silurian sandstones: granitoid boulders in conglomerates, derived from the north, that unconformably overlie the Ballantrae Complex ophiolite have Rb-Sr ages of about $470 \mathrm{Ma}$ (Longman et al. 1979); a granitoid boulder in a conglomerate, derived from the north, within the northern part of the Southern Uplands terrane has given a U-Pb monazite age of about $474 \mathrm{Ma}$ (Bluck et al. 2006); U-Pb zircon ages from Silurian sandstones of the Midland Valley terrane show a peak at about $475 \mathrm{Ma}$ (Phillips et al. 2009) 
Within the Tyrone Igneous Complex, the Tyrone Central Inlier most probably represents one of a number of lenticular microcontinental blocks detached from the Laurentian margin during the opening of the Iapetus Ocean and then sequentially reattached during the Grampian Event of the Caledonian Orogeny, at about $470 \mathrm{Ma}$. During this event, there was widespread and polyphase arc-continent collision and ophiolite obduction (e.g. Chew et al. 2010; Hollis et al. 2012). Reconstructions of events at Tyrone have favoured development of the igneous complex above a northdipping subduction zone. At Ballantrae, a south-dipping subduction zone has been preferred for the generation of the suprasubduction-zone ophiolite, followed by a polarity switch to north-dipping after arc-continent collision, albeit the evidence is flimsy.

A similarity of the tectonic position of the Tyrone Igneous Complex relative to the Tyrone Central Inlier, with that of the Ballantrae Complex at the southern margin of the Midland Valley microcontinental block was probably responsible for the interpretation of Kawai et al. (2008) showing the obduction of the Ballantrae ophiolite onto a basement of Dalradian and Moine rocks (their figure 12c). However, the comparison founders on the likely dissimilarity between the Tyrone Central Inlier and the basement to the Scottish Midland Valley terrane. The Midland Valley basement is nowhere exposed, but several lines of indirect evidence (summarised by Bluck 2001) suggest that it has a more ancient metamorphic history than has the Dalradian. Moreover, detrital zircons thought to have been derived from the Midland Valley basement and now contained in Silurian sandstones, have provided Proterozoic ages of about 1000-1800 Ma but a scarcity of the Archaean zircon ages seen in the Dalradian (Phillips et al. 2009). It seems most likely that the Midland Valley basement originated as a small, separately accreted continental block distinct from that now seen as the Tyrone Central Inlier. As a result, the Tyrone Igneous Complex more probably has a structural setting in common with the Highland Border Complex, despite its overlap in age and lithology with the Ballantrae Complex.

\section{Conclusions}


The broad interpretation of the Ballantrae Complex as an ophiolite assemblage, generated within the Iapetus Ocean and accreted at the margin of Laurentia as that ocean began to close, is now well established. Radiometric dates and graptolite biostratigraphy prove that components of the complex range in age from Neoproterozoic to early Ordovician but are mostly Arenig (Floian) and were obducted at the continental margin at about $470 \mathrm{Ma}$. However, it should be noted that most of the radiometric dates have relatively large errors and the most precise age control is provided by the graptolites found in sedimentary interbeds within some of the lava successions. The geochemical characteristics of those volcanic lavas show that they were erupted in a range of oceanic environments: island arcs, oceanic islands and back-arc spreading zones. Features of the ultramafic rocks, now pervasively serpentinised, suggest that they too were derived from a supra-subduction, island arc setting. Taken together, the various lines of evidence point to an early Arenig marginal basin, incorporating some older elements, which was tectonically disrupted and compressed during an obduction event driven by arc-continent collision. It is possible that ridge subduction occurred at some stage in the development of the arc, opening a window in the descending oceanic crust by slab break off and so permitting basalts of within-plate type to be erupted.

However, despite the general consensus as to the age and origin of the Ballantrae Complex there remain areas of uncertainty. Did it develop through a continuum of events in a general arc - marginal basin setting, or was there tectonic juxtaposition of assemblages generated in disparate settings drawn from a considerable range not only of vertical but also of horizontal distances? Metamorphic grade is for the most part relatively low, but the presence of a range of higher-grade metamorphic rocks notably blueschists - suggests a complicated and probably polyphase structural history, whilst the relative importance of serpentinite diapirism versus compressional and strike-slip tectonics remains unresolved. Arc-arc collision within a wholly oceanic environment may have destroyed an early 'marginal' basin with the structurally imbricated remnants forming the foundation of the better-defined, Arenig arc and back-arc assemblage.

Though it is common to refer to the Ballantrae Complex as having been obducted onto the continental margin of Laurentia, the processes involved and the relationships 
that they generated are not entirely clear. It is highly probable that some components of the complex that are now structurally juxtaposed originated at a considerable distance from each other and were brought together by strike-slip movement. As now assembled, the Ballantrae Complex lies at the southern margin of the Midland Valley terrane, which is underpinned by a continental basement that appears to differ fundamentally from adjacent parts of the Laurentian margin. What evidence there is suggests that rather than being obducted onto the Midland Valley basement, the Ballantrae Complex occupies a steeply inclined fault zone separating the Midland Valley from the Southern Uplands terrane to the south although the latter terrane is itself partly allochthonous on 'Midland valley-type' basement. This relationship, and the seemingly individual character of the Midland Valley basement, would seem to preclude any regional correlation with the broadly coeval ophiolites of the Highland Border Complex and the Tyrone Igneous Complex.

\section{Acknowledgements}

My appreciation of the Ballantrae Complex has been enhanced by collaboration with many colleagues, of whom I should like to thank Dr Adrian Rushton and Professor John Smellie in particular. I am grateful to Dr Mark Cooper for discussion of the Tyrone Igneous Complex and to Dr Doug Fettes and Dr Diarmad Campbell for discussion of an early draft of this paper, which is published by permission of the Executive Director, British Geological Survey (NERC). I should also like to record my sincere thanks to the referees, Professor Brian Bluck and Dr Steve Hollis, for their generous, perceptive and extremely helpful reviews, and to Dr Maarten Krabbendam for his editorial advice. The quality of the figures is entirely due to the skill of Craig Woodward.

\section{References}

Aitchison, J.C. 1998. A Lower Ordovician (Arenig) radiolarian fauna from the Ballantrae Complex, Scotland. Scottish Journal of Geology. 34, 73-81.

Anderson, J.G.C. 1936. Age of the Girvan-Ballantrae serpentine. Geological Magazine, 73, 535-545. 
Armstrong, H.A., Owen, A.W. \& Floyd, J.D. 1999. Rare earth geochemistry of Arenig cherts from the Ballantrae Ophiolite and Leadhills Imbricate Zone, southern Scotland: implications for origin and significance to the Caledonian Orogeny. Journal of the Geological Society, London. 156, 549-560.

Bailey, E.B. \& McCallien, W.J. 1952. Ballantrae problems: historical review. Transactions of the Edinburgh Geological Society, 15, 14-38.

Bailey, E.B. \& McCallien, W.J. 1957. The Ballantrae Serpentine, Ayrshire. Transactions of the Edinburgh Geological Society, 17, 33-53.

Balsillie, D. 1932. The Ballantrae Igneous Complex, South Ayrshire. Geological Magazine, 69, 107-131.

Balsillie, D. 1935. Age-relations of the Ballantrae Igneous Complex, South Ayrshire. University Press, St Andrews. 3 pp.

Balsillie, D.1936. Lewisian Rocks in South Scotland. The Scotsman, 11 April, p 13.

Balsillie, D. 1937. Further observations on the Ballantrae Igneous Complex, South Ayrshire. Geological Magazine, 74, 20-33.

Barrett, T.J., Jenkyns, H.C. Leggett, J.K. \& Robertson, A.H.F. 1981. Volcanic stratigraphy and possible tectonic setting of the Ballantrae ophiolite complex, S.W. Scotland. Ofioliti, 6, 165-166.

Barrett, T.J., Jenkyns, H.C. Leggett, J.K. \& Robertson, A.H.F. 1982. Comment on "Age and origin of Ballantrae ophiolite and its significance to the Caledonian orogeny and Ordovician time scale" with Reply by Bluck, B. J. \& Halliday, A. N. Geology, 10, 331-333.

Bergström, S.M. 1971. Conodont biostratigraphy of the Middle and Upper Ordovician of Europe and Eastern North America. In: Sweet, W.C. \& Bergström, S.M. (eds) Symposium on Conodont Biostratigraphy. Geological Society of America Memoir, 127, 83-161.

Bergström, S.M. 1980. Conodonts as palaeotemperature tools in Ordovician rocks of the Caledonides and adjacent areas in Scandinavia and the British Isles. Geologiska Föreningans i Stockholm Förhandlingar, 102, 377-392.

Bloxam, T.W. 1954. Rodingite from the Girvan-Ballantrae Complex, Ayrshire. Mineralogical Magazine, 30, 525-528.

Bloxam, T.W. 1955. The origin of the Girvan-Ballantrae beerbachites. Geological Magazine, 92, 329-337.

Bloxam, T.W. 1964. Hydrogrossular from the Girvan-Ballantrae Complex, Ayrshire. Mineralogical Magazine, 33, 814-815. 
Bloxam, T.W. 1968. Petrology of Byne Hill, Ayrshire. Transactions of the Royal Society of Edinburgh, 68, 105-122.

Bloxam, T.W. 1980. Amphibolite contact zones, amphibolite xenoliths, and blueschists associated with serpentinite in the Girvan-Ballantrae Complx, Southwest Scotland. Archive des Sciences, 33, 291-299.

Bloxam, T.W. \& Allen, J.B. 1960. Glaucophane schist, eclogite and associated rocks from Knockormal in the Girvan-Ballantrae Complex, south Ayrshire. Transactions of the Royal Society of Edinburgh, 64, 1-27.

Bloxam, T.W. \& Lewis, A.D. 1972. Ti, Zr, and Cr in some British pillow lavas and their petrogenetic affinities. Nature Physical Science, 237, 134-136.

Bluck, B.J. 1978. Geology of a continental margin 1: the Ballantrae Complex. In: Bowes, D.R \& Leake, B.E. (eds) Crustal evolution in northwestern Britain and adjacent regions. Geological Journal Special Issue, 10, 151-162.

Bluck, B.J. 1982. Hyalotuff deltaic deposits in the Ballantrae ophiolite of SW Scotland: evidence for crustal position of the lava sequence. Transactions of the Royal Society of Edinburgh: Earth Sciences, 72 (for 1981), 217-228.

Bluck, B.J. 1983. Role of the Midland Valley of Scotland in the Caledonian Orogeny. Transactions of the Royal Society of Edinburgh: Earth Sciences, 74, 119-136.

Bluck, B.J. 1984. Pre-Carboniferous history of the Midland Valley of Scotland. Transactions of the Royal Society of Edinburgh: Earth Sciences, 75, 275-295.

Bluck, B.J. 1985. The Scottish paratectonic Caledonides. Scottish Journal of Geology, 21, 437-464.

Bluck, B.J. 1992. Bennane Head to Downan Point. In: Lawson, J.D. \& Weedon, D.S. (eds) Geological Excursions around Glasgow and Girvan. Geological Society of Glasgow. 347-361.

Bluck, B.J. 2001. Caledonian and related events in Scotland. Transactions of the Royal Society of Edinburgh: Earth Sciences, 91, 375-404.

Bluck, B.J. 2010. The Highland Boundary Fault and the Highland Border Complex. Scottish Journal of Geology, 46, 113-124.

Bluck, B.J., Halliday, A.N., Aftalion, M. and Macintyre, R.M. 1980. Age and origin of Ballantrae ophiolite and its significance to the Caledonian orogeny and Ordovician time scale. Geology, 8, 492-495.

Bluck, B.J., Dempster, T.J., Aftalion, M., Haughton, P.D.W. \& Rogers, G. 2006. Geochronology of a granitoid boulder from the Corsewall Formation (Southern Uplands): implications for the evolution of southern Scotland. Scottish Journal of Geology, 42, 29-35. 
Bonney, T.G. 1878. On the serpentine and associated igneous rocks of the Ayrshire coast. Quarterly Journal of the Geological Society, London. 34, 769-785.

British Geological Survey. 1988. Ballantrae. Scotland Sheets NX 08, 18 and 19 (in part). Solid Geology. 1:25 000. British Geological Survey, Keyworth, Nottingham.

British Geological Survey. 2006. Regional Geophysics of Southern Scotland and Northern England. Compact Disc. British Geological Survey, Keyworth, Nottingham.

Cawood, P.A., Merle, R.E., Strachan, R.A. \& Tanner, P.W.G. 2012. Provenance of the Highland Border Complex: constraints on Laurentian margin accretion in the Scottish Caledonides. Journal of the Geological Society, London, 169, 575-586.

Chew, D.M., Daly, J.S., Magna, T., Page, L.M., Kirkland, C.L., Whitehouse, M.J. \& Lam, R. 2010. Timing of ophiolite obduction in the Grampian orogen. Geological Society of America Bulletin, 122, 1787-1799.

Chew, D.M., Flowerdew, M.J., Page, L.M., Crowley, Q.G., Daly, J.S., Cooper, M. \& Whitehouse, M.J. 2008. The tectonothermal evolution and provenance of the Tyrone Central Inlier, Ireland: Grampian imbrication of an outboard Laurentian microcontinent. Journal of the Geological Society, London, 165, 675-685.

Church, W.R. \& Gayer, R.A. 1973. The Ballantrae Ophiolite. Geological Magazine, 110, 497-510.

Cocks, L.R.M. \& Toghill, P. 1973. The biostratigraphy of the Silurian rocks of the Girvan district, Scotland. Journal of the Geological Society, London, 129, 209-243.

Coleman, R.G. 1977. Ophiolites. Ancient Oceanic Lithosphere? Springer-Verlag, Berlin, Heidelberg and New York. 229 pp.

Colman-Sadd, S.P., Stone, P., Swinden, H.S. and Barnes, R.P. 1992. Parallel geological development in the Dunnage Zone of Newfoundland and the Lower Palaeozoic terranes of southern Scotland: an assessment. Transactions of the Royal Society of Edinburgh: Earth Sciences, 83, 571-594.

Cooper, M.R. \& Mitchell, W.I. 2004. Midland Valley Terrane. In: Mitchell, W.I. (ed.) The Geology of Northern Ireland. Our Natural Foundation. Geological Survey of Northern Ireland, Belfast. 25-40.

Cooper, M.R., Crowley, Q.G. \& Rushton, A.W.A. 2008. New age constraints for the Ordovician Tyrone Volcanic Group, Northern Ireland. Journal of the Geological Society, London, 165, 333-339.

Cooper, M.R., Crowley, Q.G., Hollis, S.P., Noble, S.R., Roberts, S., Chew, D., Earls, G., Herrington, R. \& Merriman, R.J. 2011. Age constraints and geochemistry of the Ordovician Tyrone Igneous Complex, Northern Ireland: implications for the Grampian orogeny. Journal of the Geological Society, London, 168, 837-850.

Crawford, A.J. 1989. Boninites. Unwin Hyman, London. 465 pp. 
Curry, G.B., Bluck, B.J., Burton, C.J., Ingham, J.K., Siveter, D.J \& Williams, A. 1984. Age, evolution and tectonic history of the Highland Border Complex, Scotland. Transactions of the Royal Society of Edinburgh: Earth Sciences, 75, 113-133.

Dewey, J.F. 1971. A model for the Lower Palaeozoic evolution of the southern margin of the early Caledonides of Scotland and Ireland. Scottish Journal of Geology, 7, 219-240.

Dewey, J.F. \& Shackleton, R.M. 1984. A model for the evolution of the Grampian tract in the early Caledonides and Appalachians. Nature, London, 312, 115-121.

Dewey, J.F., Rickards, R.B. \& Skevington, D. 1970. New light on the age of Dalradian deformation and metamorphism in western Ireland. Norsk Geologisk Tidsskrift, 50, 19-44.

Dick, H.J.B. \& Bullen, T. 1984. Chromian spinel as a petrogenetic indicator in abyssal and alpine-type peridotites and spatially associated lavas. Contributions to Mineralogy and Petrology, 86, 54-76.

Draut, A.E., Clift, P.D., Amato, J.M., Blusztajn, J. \& Schouten, H. 2009. Arccontinent collision and the formation of continental crust: a new geochemical and isotopic record from the Ordovician Tyrone Igneous Complex, Ireland. Journal of the Geological Society, London, 166, 485-500.

Falloon, T.J., Malahoff, A. Zonenshain, L.P. \& Bogdanov, Y. 1992. Petrology and geochemistry of back-arc basin basalts from the Lau Basin spreading ridges at $15^{\circ}$, $18^{\circ}$ and $19^{\circ} \mathrm{S}$. Mineralogy and Petrology, 47, 1-35.

Floyd, J.D. 1999. Geology of the Carrick-Loch Doon district. Memoir of the British Geological Survey, sheets 8W and 8E (Scotland).

Floyd, J.D. \& Williams, M. 2003. A revised correlation of Silurian rocks in the Girvan district, SW Scotland. Transactions of the Royal Society of Edinburgh: Earth Sciences, 93 (for 2002), 383-392.

Forbes, D. 1867. On the alleged hydrothermal origin of certain granites and metamorphic rocks. Geological Magazine, 4, 49-59 \& 225-230.

Geikie, J. 1866. On the metamorphic Lower Silurian rocks of Carrick, Ayrshire. Quarterly Journal of the Geological Society, London, 22, 513-534

Geikie, A. \& Geikie, J. 1869. Explanation of Sheet 7. Ayrshire, south-western District. Memoirs of the Geological Survey, Scotland. 16 pp.

Gradstein, F.M., Ogg, J.G., Schmitz, M.D. \& Ogg, G.M. (eds). 2012. The Geologic Time Scale 2012. Elsevier, Oxford, Amsterdam \& Waltham MA. 
Hamilton, P.J, Bluck, B.J \& Halliday, A.N. 1984. Sm-Nd ages from the Ballantrae complex, SW Scotland. Transactions of the Royal Society of Edinburgh: Earth Sciences, 75, 183-187.

Harris, P.M., Farrar, E., MacIntyre, R.M. \& York, D. 1965. Potassium-Argon age measurements on two igneous rocks from the Ordovician System of Scotland. Nature, London, 205, 352-353.

Hollis, S.P., Roberts, S., Cooper, M.R., Earls, G., Herrington, R., Condon, D.J., Cooper, M.J., Archibald, S.M. \& Piercey, S.J. 2012. Episodic arc-ophiolite emplacement and the growth of continental margins: Late accretion in the Northern Irish sector of the Grampian-Taconic orogeny. Geological Society of America Bulletin, 124, 1702-1723.

Hollis, S.P., Cooper, M.R., Roberts, S., Earls, G., Herrington, R., Condon, D.J. \& Daly, J.S. 2013 (a). Evolution of the Tyrone ophiolite, Northern Ireland, during the Grampian-Taconic orogeny: a correlative to the Annieopsquotch Ophiolite Belt of central Newfoundland? Journal of the Geological Society, London, 170, 861-876.

Hollis, S.P., Cooper, M.R., Roberts, S., Earls, G., Herrington, R. \& Condon, D.J. 2013 (b). Stratigraphic, geochemical and U-Pb zircon constraints from Slieve Gallion, Northern Ireland: a correlation of the Irish Caledonian arcs. Journal of the Geological Society, London, 170, 737-752.

Holub, F.V., Klápová, H., Bluck, B.J. \& Bowes, D.R. 1984. Petrology and geochemistry of post-obduction dykes of the Ballantrae complex, SW Scotland. Transactions of the Royal Society of Edinburgh: Earth Sciences, 75, 211-223.

Ince, D. 1984. Sedimentation and tectonism in the Middle Ordovician of the Girvan district, SW Scotland. Transactions of the Royal Society of Edinburgh: Earth Sciences, 75, 225-237.

Jelínek, E., Souček, J., Bluck, B.J., Bowes, D.R. \& Treloar, P.J. 1980. Nature and significance of beerbachites in the Ballantrae ophiolite, SW Scotland. Transactions of the Royal Society of Edinburgh: Earth Sciences, 71, 159-179.

Jelínek, E., Souček, J., Řanda, Z., Jakeš, P., Bluck, B.J. \& Bowes, D.R. 1984. Geochemistry of peridotites, gabbros and trondhjemites of the Ballantrae complex, SW Scotland. Transactions of the Royal Society of Edinburgh: Earth Sciences, 75, 193-209.

Jones, C.M. 1977. The Ballantrae complex as compared to the ophiolites of Newfoundland. Unpublished $\mathrm{PhD}$ thesis, University of Wales. $417 \mathrm{pp}$.

Kawai, T., Windley, B.F., Shibuya, T., Omori, S., Sawaki, Y. \& Maruyama, S. 2008. Large P-T gap between Ballantrae blueschist/garnet pyroxenite and surrounding ophiolite, southern Scotland, UK: Diapiric exhumation of a Caledonian serpentinite mélange. Lithos, 104, 337-354. 
Kimbell, G.S. \& Stone, P. 1995. Crustal magnetization variations across the Iapetus Suture Zone. Geological Magazine, 132, 599-609.

Lamont, A. \& Lindström, M. 1957. Arenigian and Llandeilian Cherts identified in the Southern Uplands of Scotland by means of Conodonts, etc. Transactions of the Edinburgh Geological Society, 17, 60-71 + 1 plate.

Lapworth, C. 1889. On the Ballantrae rocks of South Scotland and their place in the Upland sequence. Geological Magazine, 6, 20-24 \& 59-69.

Lewis, A.D. \& Bloxam, T.W. 1977. Petrotectonic environments of the GirvanBallantrae lavas from rare-earth element distributions. Scottish Journal of Geology, 16, 181-188.

Longman, C.D., Bluck, B.J. \& van Breeman, O. 1979. Ordovician conglomerates and the evolution of the Midland Valley. Nature, London, 280, 578-581.

Maletz, J. 2004. Late Castlemainian (Ca 4, Arenig) graptolites from the Ballantrae Complex, SW Scotland: discussion, with reply by Stone, P \& Rushton, A.W.A. Scottish Journal of Geology, 40, 185-187.

McKerrow, W.S., Mac Niocaill, C. \& Dewey, J.F. 2000. The Caledonian Orogeny redefined. Journal of the Geological Society, London, 157, 1149-1154.

Mitchell, A.H.G. 1978. The Grampian Orogeny in Scotland: arc-continent collision and polarity reversal. Journal of Geology, 86, 643-646.

Murchison, R.I. 1851. On the Silurian Rocks of the South of Scotland. Quarterly Journal of the Geological Society, London, 7, 137-178.

Oliver, G.J.H. 2002. Chronology and terrane assembly, new and old controversies. In: Trewin, N.H. (ed.) The Geology of Scotland. The Geological Society, London, 201211.

Oliver, G.J.H. \& McAlpine, R.R. 1998. Occurrence of a sheeted dolerite dyke complex in the Ballantrae ophiolite, Scotland. Geological Magazine, 135, 509-517.

Oliver, G.J.H., Stone, P. \& Bluck, B.J. 2002. The Ballantrae Complex and Southern Uplands terrane. In: Trewin, N.H. (ed.) The Geology of Scotland. The Geological Society, London, 167-200.

Peach, B.N. \& Horne, J. 1899. The Silurian Rocks of Britain. Vol 1. Scotland. Memoirs of the Geological Survey of the United Kingdom. HMSO. 749 pp.

Pearce, J.A. \& Cann, J.R. 1973. Tectonic setting of basic volcanic rocks determined using trace element analyses. Earth and Planetary Science Letters, 19, 290-300.

Pearce, J.A. \& Norry, M.J. 1979. Petrogenetic implications of Ti, Zr, Y and Nb variations in volcanic rocks. Contributions to Mineralogy and Petrology, 69, 33-47. 
Pearce, J.A., Lippard, S.J. \& Roberts, S. 1984. Characteristics and tectonic significance of supra-subduction zone ophiolites. In: Kokelaar, B.P. \& Howells, M.F. (eds) Marginal basin geology. Volcanic and associated sedimentary and tectonic processes in modern and ancient marginal basins. Geological Society, London, Special Publications, 16, 77-94.

Phillips, E.R., Smith, R.A., Stone, P., Pashley, V. \& Horstwood, M. 2009. Zircon age constraints on the provenance of Llandovery to Wenlock sandstones from the Midland Valey terrane of the Scottish Caledonides. Scottish Journal of Geology, 45, 131-146.

Powell, D.W. 1978 . Geology of a continental margin 3: gravity and magnetic anomaly interpretation of the Girvan-Ballantrae district. In: Bowes, D.R \& Leake, B.E. (eds) Crustal evolution in northwestern Britain and adjacent regions. Geological Journal Special Issue, 10, 151-162.

Power, M.R. \& Pirrie, D. 2003. Platinum-Group Minerals within the Ballantrae Complex, SW Scotland. Scottish Journal of Geology, 39, 1-5.

Pringle, J. 1933. Report of Summer Field Meeting, 1932: Girvan-Ballantrae. Proceedings of the Geologists' Association, 44, 57-59.

Pringle, J. 1935. British Regional Geology: South of Scotland (First edition). Edinburgh, HMSO. 97 pp.

Robertson, A.H.F. \& Henderson, W.G. 1984. Geochemical evidence for the origins of igneous and sedimentary rocks of the Highland Border, Scotland. Transactions of the Royal Society of Edinburgh: Earth Sciences, 75, 135-150.

Rushton A.W.A. \& Stone, P. 1988. Graptolite faunas from the Ballantrae Complex. Letter to the Editors. Scottish Journal of Geology, 24, 93-95.

Rushton, A.W.A., Stone, P., Smellie, J.L. \& Tunnicliff, J.P. 1986. An early Arenig age for the Pinbain sequence of the Ballantrae Complex. Scottish Journal of Geology, 22, 41-54.

Sanders, R. 1760. The Complete Newgate Calendar, 1 , www.scotsites.co.uk/ebooks/sawneybeane.htm.

Sawaki, Y., Shibuya, T., Kawai, T., Komiya, T., Omori, S., Iizuka, T., Hirata, T., Windley, B.F. \& Maruyama, S. 2010. Imbricated ocean-plate stratigraphy and U-Pb zircon ages from tuff beds in cherts in the Ballantrae complex, SW Scotland. Geological Society of America Bulletin, 122, 454-464.

Smellie, J.L. 1984a. Accretionary lapilli and highly vesiculated pumice in the Ballantrae ophiolite complex: ash-fall products of subaerial eruptions. British Geological Survey Report, 16/1, 36-40.

Smellie, J.L. 1984b. Metamorphism of the Ballantrae complex, south-west Scotland: a preliminary study. British Geological Survey Report, 16/10, 13-17. 
Smellie, J.L. \& Stone, P. 1984. 'Eclogite' in the Ballantrae Complex: a garnet-clinopyroxenite segregation in mantle harzburgite? Scottish Journal of Geology, 20, 315-327.

Smellie, J.L. \& Stone, P. 1992. Geochemical control on the evolutionary history of the Ballantrae Complex, S.W. Scotland, from comparisons with recent analogues. In: Parson, L.M., Murton, B.J. \& Browning, P. (eds). Ophiolites and their modern oceanic analogues. Geological Society, London, Special Publications, 60, 171-178.

Smellie, J.L. \& Stone, P. 2001. Geochemical characteristics and geotectonic setting of early Ordovician basalt lavas in the Ballantrae Complex ophiolite, SW Scotland. Transactions of the Royal Society of Edinburgh: Earth Sciences, 91 (for 2000), 539555.

Smellie, J.L., Stone, P. \& Evans, J.A. 1995. Petrogenesis of boninites in the Ordovician Ballantrae Complex ophiolite, southwest Scotland. Journal of Volcanology and Geothermal Research, 69, 323-342.

Spray, J.G. 1982. Mafic segregations in ophiolite mantle sequences. Nature, London, 299, 524-528.

Spray, J.G. \& Williams, G.D. 1980. The sub-ophiolite metamorphic rocks of the Ballantrae Igneous Complex, SW Scotland. Journal of the Geological Society, London, 137, 359-368.

Steinmann, G. 1927. Die ophiolithischen Zonen in dem mediterranen Kettengebirge. $14^{\text {th }}$ International Geological Congress, Madrid, 2, 638-667.

Stone, P. 1982. Clastic rocks within the Ballantrae complex: borehole evidence. Report of the Institute of Geological Sciences, 82/1, 45-47.

Stone, P. 1984. Constraints on genetic models for the Ballantrae Complex, SW Scotland. Transactions of the Royal Society of Edinburgh: Earth Sciences, 75, 189191.

Stone, P. 1999. The Ballantrae Complex. In: Stephenson, D., Bevins, R.E., Millward, D., Highton, A.J., Parsons, I., Stone, P. \& Wadsworth, W.J. Caledonian Igneous Rocks of Great Britain. Geological Conservation Review Series, No. 17, Joint Nature Conservation Committee, Peterborough, 69-100.

Stone, P. \& Rushton, A.W.A. 1983. Graptolite faunas from the Ballantrae ophiolite complex and their structural implications. Scottish Journal of Geology, 19, 297-310.

Stone, P. \& Rushton, A.W.A. 2003. A Late Arenig (early Yapeenian) graptolite fauna and the coeval tectonic development of the Ballantrae Complex, SW Scotland.

Scottish Journal of Geology, 39, 29-40.

Stone, P. \& Smellie, J.L. 1988. The Ballantrae area: a description of the solid geology of parts of 1:25 000 sheets NX08, 18 and 19. Classical areas of British Geology. HMSO for British Geological Survey. 125 pp. 
Stone, P. \& Smellie, J.L. 1990. The Ballantrae ophiolite, Scotland: an Ordovician island arc - marginal basin assemblage. In: Malpas, J.A., Moores, E.M., Panayiotou, A \& Xenophontos, C. (eds). Ophiolites - oceanic crustal analogues. Proceedings of the Troodos 87 symposium. Geological Survey Dept. Nicosia, Cyprus. 533-546.

Stone, P. \& Strachan, I. 1981. A fossiliferous borehole section within the Ballantrae ophiolite. Nature, London, 293, 455-456.

Stone, P., Lambert, J.L.M., Carruthers, R.M. and Smellie, J.L. 1984. Concealed ultramafic bodies in the Ballantrae complex, south-west Scotland: borehole results. British Geological Survey Report, 84/1, 41-45.

Stone, P., Gunn, A.G., Coats, J.S. \& Carruthers, R.M. 1986. Mineral exploration in the Ballantrae complex, south west Scotland. In: Gallagher M.J., Ixer, R.A, Neary, C.R. \& Prichard, H.M. (eds) Metallogeny of basic and ultrabasic rocks. IMM, London, 265-278.

Stone, P., McMillan, A.A., Floyd, J.D., Barnes, R.P. and Phillips, E.R. 2012. British Regional Geology: South of Scotland (Fourth edition). Keyworth, Nottingham: British Geological Survey. 247 pp.

Tanner, P.W.G. 1995. New evidence that the Lower Cambrian Leny Limestone at Callander, Perthshire, belongs to the Dalradian Supergroup, and a reassessment of the 'exotic' status of the Highland Border Complex. Geological Magazine, 132, 473-483.

Tanner, P.W.G. \& Sutherland, S. 2007. The Highland Border Complex, Scotland: a paradox resolved. Journal of the Geological Society, London, 164, 111-116.

Tanner, P.W.G., Armstrong, H.A. \& Owen, A.W. 2013. Rare earth element and LaTh-Sc analysis of cherts from the Highland Border Complex, Scotland: Geochemical determination of the sedimentary environment in greenschist facies rocks. Scottish Journal of Geology, 49, 15-31.

Thirlwall, M.F. \& Bluck, B.J. 1984. Sr-Nd isotope and geological evidence that the Ballantrae "ophiolite", SW Scotland, is polygenetic. In: Gass, I.G., Lippard, S.J. and Shelton, A.W. (eds.), Ophiolites and oceanic lithosphere. Geological Society, London, Special Publication. 13, 215-230.

Trench, A., Bluck, B.J. \& Watts, D.R. 1988. Palaeomagnetic studies within the Ballantrae Ophiolite, southwest Scotland: magnetotectonic and regional tectonic implications. Earth and Planetary Science Letters, 90, 431-448.

Treloar, P.J., Bluck, B.J., Bowes, D.R. \& Dudek, A. 1980. Hornblende-garnet metapyroxenite beneath serpentinite in the Ballantrae complex of SW Scotland and its bearing on the depth provenance of obducted oceanic lithosphere. Transactions of the Royal Society of Edinburgh: Earth Sciences, 71, 201-212.

Van Staal, C.R., Dewey, J.F., Mac Niocaill, C. \& McKerrow, W.S. 1998. The Cambrian-Silurian tectonic evolution of the northern Appalachians and British Caledonides: history of a complex, west and southwest Pacific-type segment of 
Iapetus. In: Blundell, D.J. \& Scott, A.C. (eds) Lyell: the Past is the Key to the Present. Geological Society, London, Special Publications, 143, 199-242.

Whyte, F. 1964. The Heads of Ayr Vent. Transactions of the Geological Society of Glasgow, 25, 72-97.

Wilkinson, J.M. \& Cann, J.R. 1974. Trace elements and tectonic relationships of basaltic rocks in the Ballantrae igneous complex, Ayrshire. Geological Magazine, 111, 35-41.

Williams, A. 1962. The Barr and Lower Ardmillan Series (Caradoc) of the Girvan district of south-west Ayrshire, with descriptions of the brachiopoda. Geological Society, London, Memoir No. 3, 267 pp.

\section{Figure Captions}

Figure 1 ... The geographical and structural position of the Ballantrae Complex, SW Scotland, showing the outline geology and the location of localities cited in the text. The geology of the complex is taken from Stone \& Smellie (1988).

Figure 2 ... The distribution within the Ballantrae Complex of basalt lava types originating in different geotectonic settings; after Smellie \& Stone (2001).

Figure 3 ... Potential evolutionary pathways in a supra-subduction zone setting that would allow geographically proximal eruption of different lava types: $a-b$, back arc extension after Smellie \& Stone (2001); a - c, ridge subduction after Kawai et al. (2008).

Figure 4 ... Models to explain magnetic anomalies along NW-SE profiles crossing the likely concealed extension of the Ballantrae Complex: A-B after Kimbell \& Stone (1995); C-D after Kimbell in Floyd (1999).

Figure 5 ... The distribution of ultramafic rocks within the Ballantre Complex, after Stone \& Smellie (1988). 
Figure 6 ... The variation of basalt lava types present in the Ballantrae Complex illustrated by geochemical discrimination diagrams after Pearce \& Cann (1973) and Pearce \& Norry (1979), and a representative selection of N-MORB and chondritenormalised multi-element diagrams. For analytical details, normalising values, additional representations and further discussion see Smellie \& Stone (2001).

Figure 7 ... A summary of the information pertaining to the age of the Ballantrae Complex: time scale after Gradstein et al. (2012).

Figure 8 ... A series of naïve, 2-D cartoons that attempt to demonstrate the relationship of the events that constructed the Ballantrae Complex to the larger-scale tectonic processes that closed the Iapetus Ocean and consolidated the terranes of southern Scotland; expanded from Stone et al. 2012, fig. 4, and assuming initially south-directed subduction. 


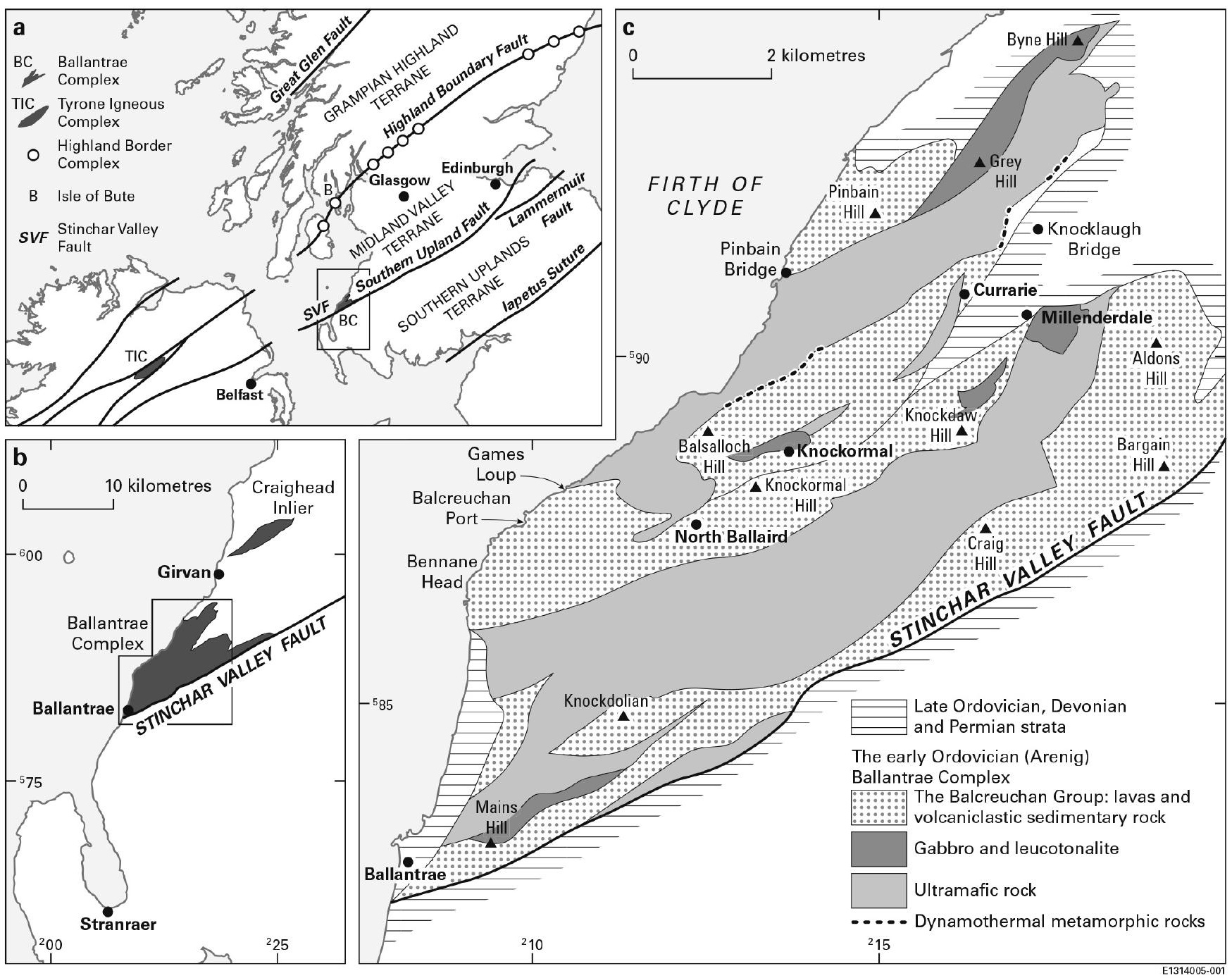




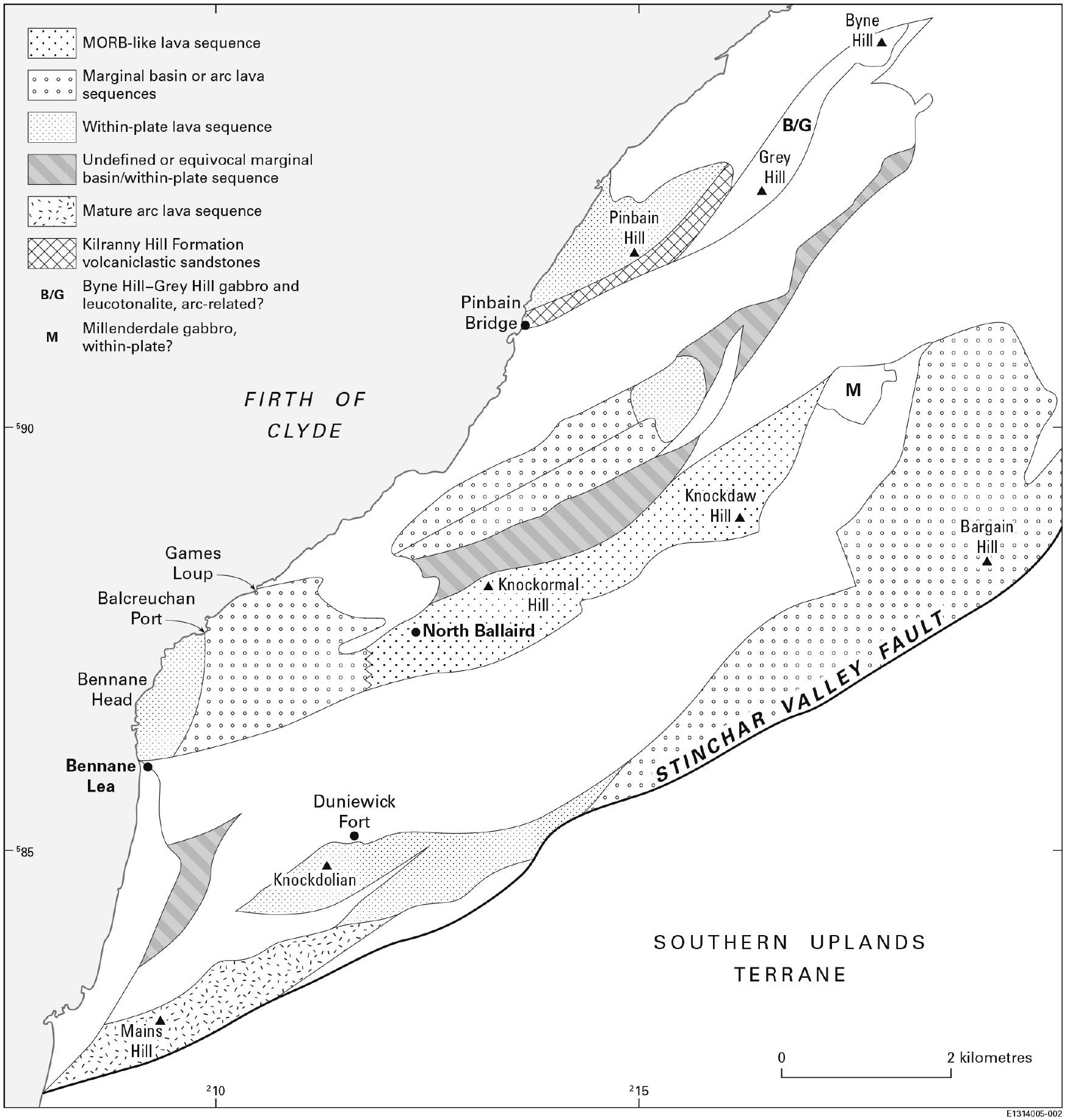




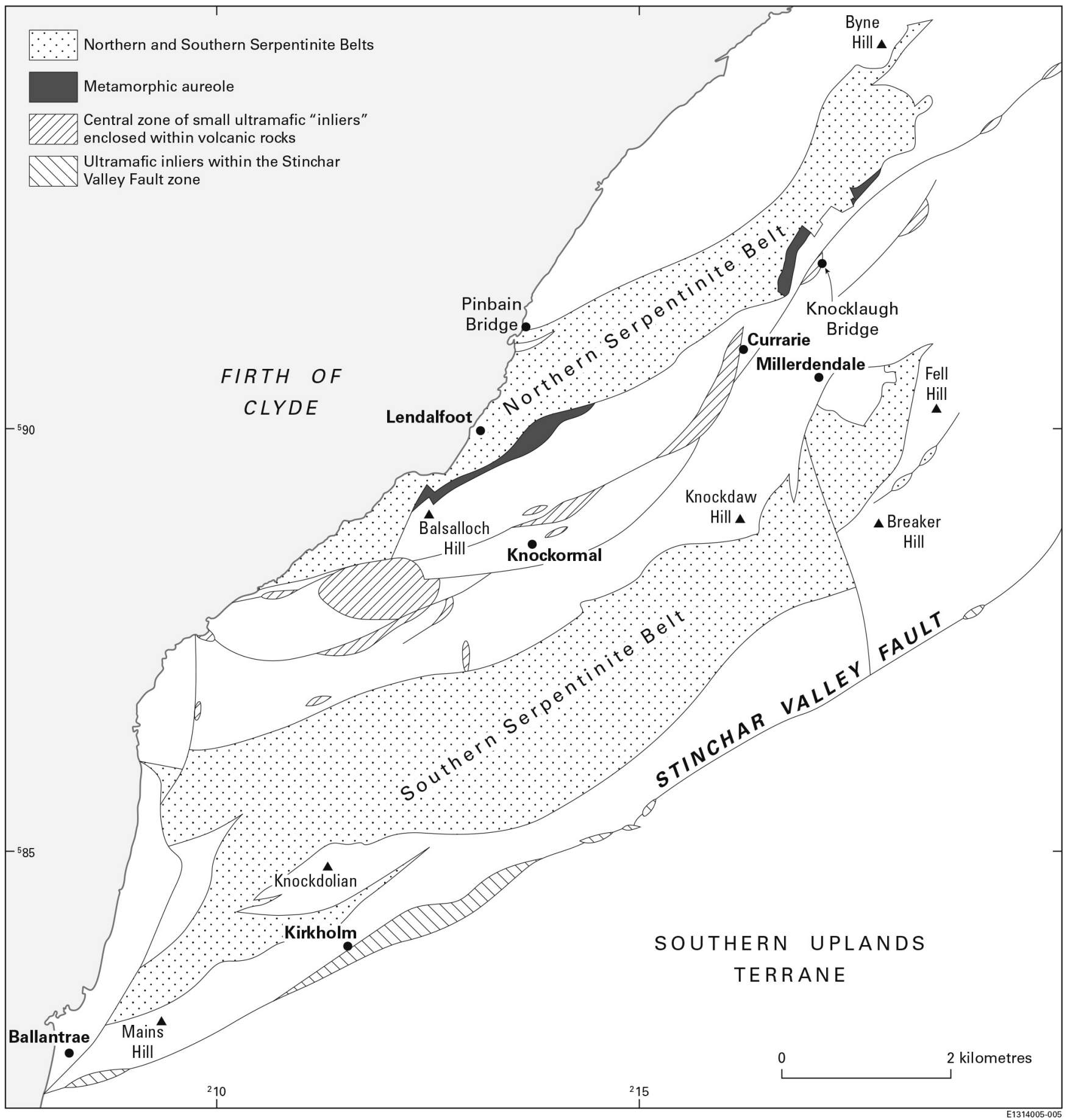


a $10, \mathbf{A}$ Arc basalt

B MORB

C WPB

D MORB, arc basalt

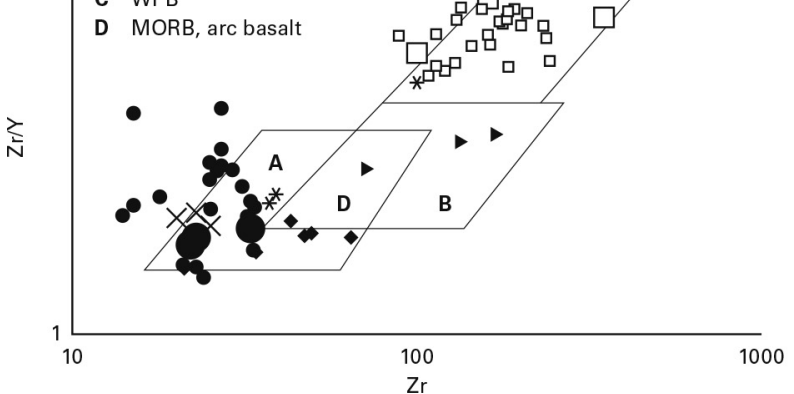

Lavas

․ Pinbain, Bennane, Knockdolian

- Balcreuchan, Games Loup, Balsalloch

- Bargain Hill

Mains Hill

- Knockormal, Knockdaw

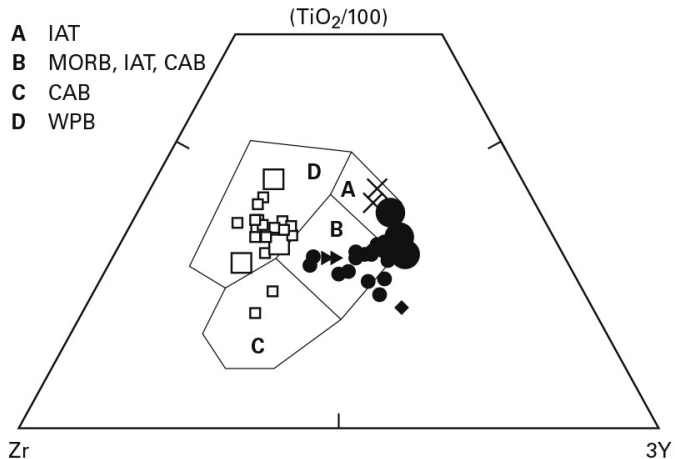

Gabbros

$\times \quad$ Byne Hill, Grey Hill

Millenderdale

Other

* Kilranny Formation (sandstones) b

Island arc

Balcreuchan, Games Loup, Balsalloch
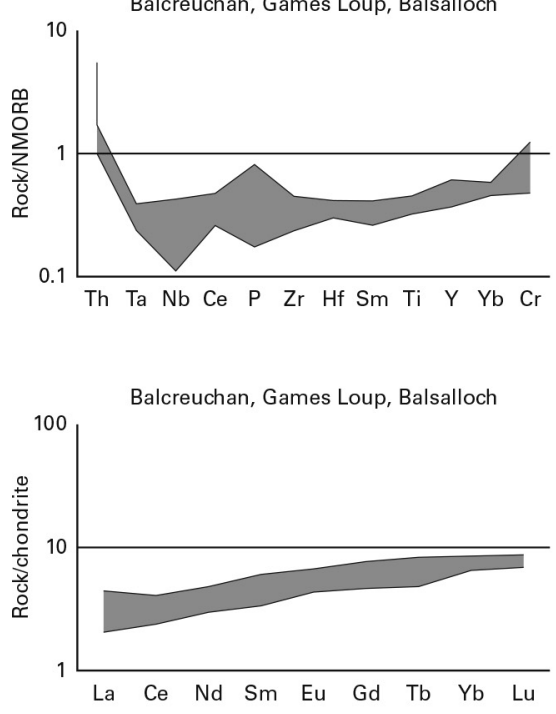

MORB/BABB

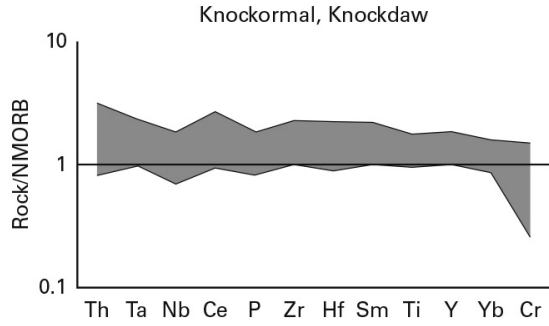

Knockormal, Knockdaw

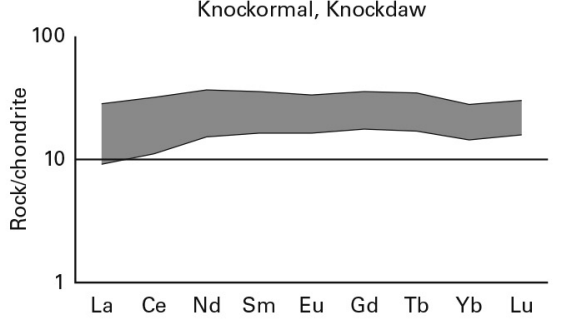

Within plate

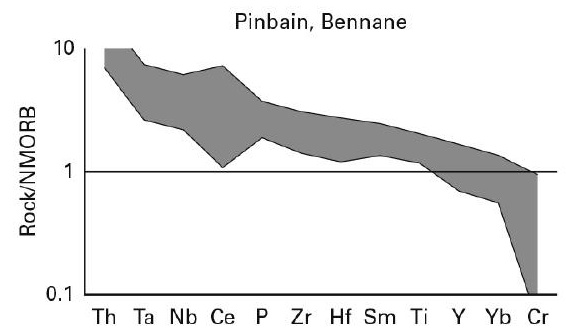

Pinbain, Bennane

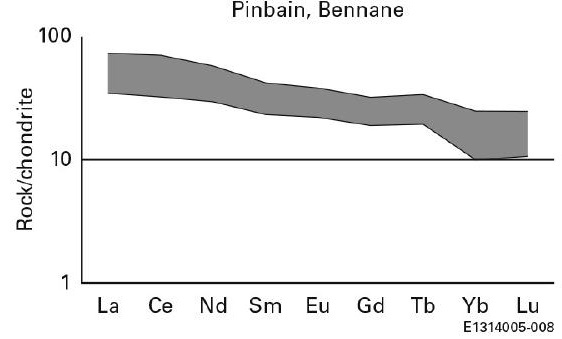




\section{a}

Summary of age control

$\mathrm{Ma}$

450
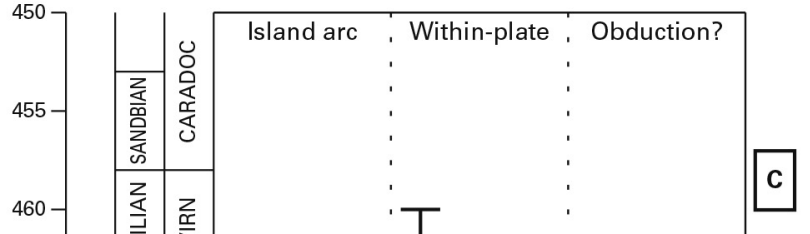

$465-\frac{z}{\frac{z}{u}}$

47$$
\begin{aligned}
& 475- \\
& 480- \\
& 485- \\
& 490- \\
& 495- \\
& 500- \\
& 505- \\
& 510- \\
& 515-
\end{aligned}
$$

\footnotetext{
$a^{\prime}$
}

$501 \pm 12 \mathrm{Ma}$, basalt, Sm-Nd Thirlwall \& Bluck, 1984

a2 $476 \pm 14 \mathrm{Ma}$, basalt, Sm-Nd

Thirlwall \& Bluck, 1984

a3 $483 \pm 4 \mathrm{Ma}$, zircon in leucotonalite,

\section{$\mathrm{U}-\mathrm{Pb}$}

Bluck et al., 1980

a4 $470 \pm 10 \mathrm{Ma}$, zircon in tuff, U-Pb

Sawaki et al., 2010

a5 $487 \pm 8 \mathrm{Ma}$, gabbro, K-Ar Bluck et al., 1980

Hamilton et al., 1984 Bluck et al., 1980

G Graptolite faunas (see b)

Bergström, 1971

sedimentary cover
Range of individual

\section{graptolite faunas}

$\mathrm{Ma}$

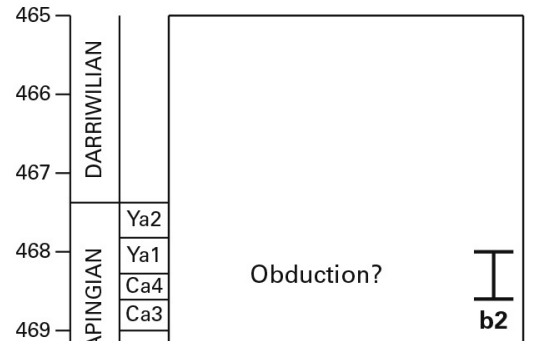

b2

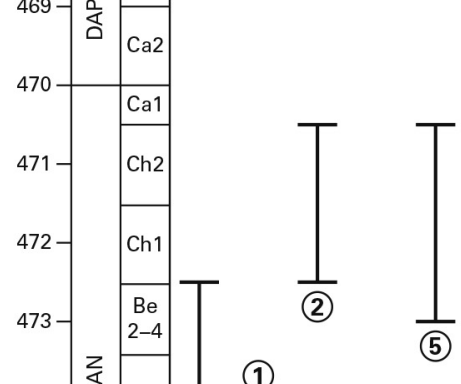

a7
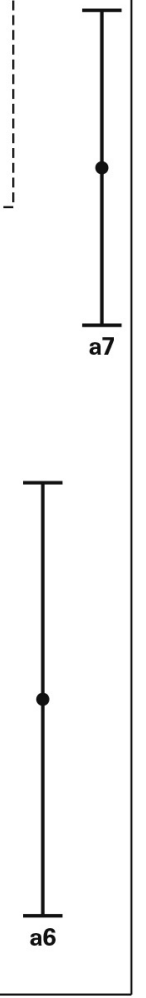

(1)

(5)

(4)

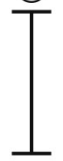

Ya Yapeenian

Ca Castlemainian

Ch Chewtonian

Be Bendigonian

La Lancefieldian

a7 $478 \pm 8 \mathrm{Ma}$, amphibolite, $\mathrm{K}-\mathrm{Ar}$

b1 Pinbain

Rushton et al., 1986

C Conodont fauna from Craighead Lamont \& Lindström, 1957;

b2 North Ballaird borehole

Stone \& Strachan, 1981

Stone \& Rushton, 2003

Maletz, 2004

(1) Locality numbers from the

Bennane Head section

Unconformable base of the 
